\title{
Prostorska analiza kmetijskih zemljišč v zaraščanju v Sloveniji
}

\author{
Matjaž GLAVAN ${ }^{1, *}$, Aljaž MALEK ${ }^{1}$, Marina PINTAR ${ }^{1}$, Helena GRČMAN $^{1}$
}

Received October 11, 2016; accepted Janury 30, 2017.

Delo je prispelo 11. oktobra 2016, sprejeto 30. januarja 2017.

\section{IZVLEČEK}

$\mathrm{V}$ prispevku je predstavljena prostorska analiza razredov dejanske rabe kmetijskih zemljišč $\mathrm{v}$ zaraščanju (razred rabe 1410) in kmetijskih zemljišč, poraslih $\mathrm{z}$ gozdnim drevjem (razred rabe 1800), $\mathrm{z}$ namenom ugotoviti vpliv izbranih naravnih dejavnikov (delež gozda, nadmorska višina, naklon površja, ekspozicija, poplavnost) in statusa upravljanja območja na pojavljanje in razporeditev teh zemljišč $\mathrm{v}$ Sloveniji. Vsi ti dejavniki vplivajo na upravljavske odločitve lastnikov. Ugotovili smo, da so zemljišča razreda rabe 1410 razporejena po celotni Sloveniji z glavnino vzdolž osi od jugozahoda proti severovzhodu, zemljišč razreda rabe 1800 je največ v jugozahodnem delu države. Na občinski ravni nismo našli izrazite povezave med deležem gozda in deležem raziskovanih razredov rab. $Z$ večanjem nadmorske višine in naklona se odstotek rabe 1410 in 1800 poveča. Ugotovili smo večjo pojavnost razreda rabe 1400 na pogosteje poplavljenih območjih. Zaraščanje je večje znotraj območij z različnimi statusi upravljanja (npr. Natura 2000). Za izboljšanje stanja in preprečevanje nadaljnjega zaraščanja bi bilo $\mathrm{v}$ statističnih regijah, kjer sta razreda rabe 1410 in 1800 najbolj prisotna, potrebno pospešeno izvajati zakon o kmetijskih zemljiščih, ki določa odpravljanje zaraščanja na območjih $\mathrm{z}$ večjo boniteto zemljišč.

Ključne besede: kmetijska zemljišča; prostorska analiza; zaraščanje; raba tal

\section{ABSTRACT \\ SPATIAL ANALYSIS OF THE ABANDONMENT OF AGRICULTURAL LAND IN SLOVENIA}

In this study we performed a spatial analysis to determine the influence of selected environmental factors (forests share, elevation a.s.l., slope, aspect, flooding) and the management status of an area on the spatial distribution of the abandoned agricultural land (land use class 1410), and agricultural land with forest trees (land use class 1800) in Slovenia. All these natural factors influence the management decisions of landowners. We found out that land use class 1410 is distributed over the entire country, along the south-west to the north-east axis. The majority of the land use class 1800 can be found in the south-western part of the country. On municipality level, the link between the forest and studied land uses was weak. The percentage of land use classes 1410 and 1800 grows with increasing altitude a.s.l. and slope. Land use class 1400 is more frequent in flooded areas. The percentage of the abandoned agricultural land is greater in areas with special management status (e.g. Natura 2000 areas). A strict, professional and fast implementation of the Agricultural Land Act is needed to improve the situation and prevent further agricultural land losses.

Key words: agricultural land; spatial analysis; abandonment; land use

\section{UVOD}

$\mathrm{Na}$ svetovni ravni delež kmetijskih površin narašča in površin gozda upada (FAOSTAT, 2013). Razlog je predvsem v krčenju gozdov za potrebe kmetovanja. Rahla rast gozdnih površin je opazna v Evropi, Aziji in tudi ponekod $\mathrm{v}$ Severni Ameriki. Izguba svetovnih gozdnih površin v obdobju od leta 1990 do 2000 je bila 8,3 milijonov ha/leto in v obdobju od leta 2000 do 2010 5,2 milijona ha/leto (FAO, 2010). Gozd obsega preko 4 milijarde ha oziroma $31 \%$ površine kopnega, na drugi strani kmetijska zemljišča skoraj 5 milijard ha oziroma $38 \%$. Primarni gozdovi (brez vpliva človeka) predstavljajo $36 \%$ površine, sekundarni (antropogeno preoblikovani) $57 \%$ in gozdne plantaže $7 \%$ (FAO, 2010). Največ gozda, glede na površino, ima Južna Amerika (49\%) in najmanj Azija (19\%). Največ kmetijskih zemljišč po površini ima Azija (53\%) in najmanj Evropa (21 \%) (FAOSTAT, 2013).

Enako kot $\mathrm{v}$ Severni Ameriki in Evropi je tudi v Sloveniji opazen trend povečanja površin gozda in upadanja kmetijskih površin (Keenleyside in Tucker, 2010; FAO, 2010; ZGS, 2011; SURS-STAT, 2012; EU, 2013). Razlogi za zmanjšanje obsega kmetijskih površin so opuščanje in zaraščanje za kmetijstvo manj ugodnih

1 Univerza v Ljubljani, Biotehniška fakulteta, Jamnikarjeva 101, 1000 Ljubljana; *corresponding author: matjaž.glavan@bf.uni-lj.si 
zemljišč ter urbanizacija za kmetijstvo ugodnejših zemljišč (Cunder, 1998; Jankovič, 2003; Hladnik, 2005). V obdobju od leta 2002 do 2007 je bilo v povprečju urbaniziranih 11 ha kmetijskih zemljišč dnevno (Vrščaj, 2008). Stopnja prehranske samooskrbe se manjša, saj za zadovoljevanje potreb prebivalcev vedno več hrane uvažamo (Plut, 2011). Na državni ravni se s preoblikovanjem krajine in vse večjim uvažanjem hrane povečujeta izguba pridelovalnega potenciala tal in prebivalstva ter prehranska odvisnost od tujine.

Zaraščanje je proces, ki nastane po prenehanju kmetijske obdelave (npr. paše, košnje, oranja) in poteka na opuščenih kmetijskih zemljiščih (FAO, 2006). Zemljišča so prepuščena naravnemu razvoju - sukcesiji. Sukcesija je spreminjanje združb organizmov v času kot posledica vpliva rastlinstva na določeno okolje. Sukcesijski proces je usmerjen, sprva v združbo z malo vrst, z medvrstnimi povezavami se razvije kompleksna (klimaksna, pedoklimaksna) združba, ki je značilna za neko okolje. Primarna sukcesija se odvija na območjih, kot so npr. ozemlja po umiku ledenika, ozemlja, prekrita z magmo, novonastali ognjeniški otoki. Sekundarna sukcesija se odvija na območjih po določeni motnji (požar, poplava), ki le delno odstrani rastlinstvo $\mathrm{s}$ prizadetega območja, ali na območjih, kjer je bila opuščena določena dejanska raba (kmetijska zemljišča, urbana zemljišča) (Wilfing, 1993; Krebs, 2001).

Vzroke oziroma dejavnike, ki otežujejo in dražijo kmetijsko pridelavo ter privedejo do opuščanja kmetijskih zemljišč, delimo na naravno pridelovalne, strukturne, socio-ekonomske in agrarno politične in so običajno medsebojno prepleteni (Cunder, 1998). Naravno pridelovalni dejavniki, ki vplivajo na kmetijsko pridelavo, so naklon, nadmorska višina, usmerjenost zemljišč (ekspozicija površja), lastnosti tal in prisotnost drugih razredov rabe na območju. Strukturni vzroki izhajajo iz neugodne lastniške in posestne strukture, kot so velikost in oblika parcel, velikost kmetijskega gospodarstva, razdrobljenost parcel, njihova oddaljenost od lastnikov in dostopnost (Cunder, 1998; Gellrich in Zimmermann, 2007; Ilc, 2008; Corbelle Rico in sod., 2012; Zaragozi in sod., 2012). Socio-ekonomski vzroki so prepleteni in vezani na lastnosti kmetovalcev in družbene razmere, kamor prištevamo spremembe tržnih razmer, splošno nezanimanje za kmetovanje, možnost zaposlitve ob kmetovanju v neposredni bližini, selitev v urbane centre in staranje prebivalstva (MacDoland in sod., 2000; Khanal in Watanabe, 2006; Ilc, 2008, Diaz in sod., 2011). Med vzroke za opuščanje kmetovanja in spodbujanje zaraščanja sodijo tudi agrarnopolitične odločitve (plačilne pravice) ter finančna (neposredna plačila) in davčna politika (katastrski dohodek), ki vplivajo na stroške pridelave (Cunder, 1998; Khanal in Watanabe, 2006). Renwick in sod. (2013) ugotavljajo, da lahko $\mathrm{v}$ primeru opustitve neposrednih plačil in ukrepov za podporo trgom v okviru skupne kmetijske politike (SKP) odstotek opuščenih površin znotraj Evropske unije naraste za $8 \%$. Nezanemarljiv je tudi vpliv naravovarstvene in okoljevarstvene zakonodaje, ki lahko spodbuja kmetijsko pridelavo (npr. ohranjanje tradicionalne kmetijske krajine na območjih Natura 2000, košnja strmih travnikov) ali opuščanje (npr. vzpostavljanje naravne vegetacije za krepitev biodiverzitete) (MacDonald in sod., 2000; Diaz in sod., 2011).

Zaraščanje opuščenih kmetijskih površin ima lahko mnogo posledic. Skupna biotska raznovrstnost se sprva zaradi naselitve pionirskih vrst poveča, a se ob vzpostavitvi kompleksnejših združb (gozd) ponovno zmanjša in ustali. Izjema je vzpostavitev monokultur, kot so nekatere invazivne vrste pri spontanem zaraščanju ali iglavci pri tvorbi plantaž (EU, 2013). Mozaičnost in heterogenost kulturne krajine se $s$ povečevanjem površine gozda manjša, kar vpliva na okolje, življenje ljudi, turizem, dostopnost za rekreacijo ipd. (Pogačnik in sod., 1995; Jankovič, 2003; Pogačnik in sod., 2011). Večje homogene enote enega razreda dejanske rabe lahko vodijo $\mathrm{V}$ poenostavljeno gospodarjenje (MacDonald in sod., 2000). Opuščena in zaraščena zemljišča predstavljajo vir nadaljnjega širjenja gozdov in divjadi, a hkrati prispevajo tudi $\mathrm{k}$ povečanju biodiverzitete (EC, 1980; Keenleyside in Tucker, 2010; Renwick in sod., 2013), stabilizaciji terena, zmanjšanju erozije tal (EU, 2013) in povečanju sposobnosti zadrževanja vode, kot je podaljšana retenzija vode v času obilnih padavin (Poyatos in sod., 2003; Garcia Ruiz in Lana Renault, 2011).

Preden se določi potrebne ukrepe za preprečevanje ali odpravljanje zaraščanja, je treba celostno analizirati vzroke opuščanja in zaraščanja kmetijskih zemljišč in na podlagi tega določiti ustrezne ukrepe za preprečevanje ali odpravljanje zaraščanja na nekem območju, če so tla primerna za kmetijsko obdelavo (Hočevar in sod., 2004; Pogačnik in sod., 2011). Če preprečevanje ali odpravljanje zaraščanja ni smiselno, se določi alternativno sedanji dejanski rabi zemljišča, ali se jih prepusti sukcesiji (Cunder, 1998; MacDonald in sod., 2000).

Zaraščajoče se površine lahko vzpostavimo nazaj v kmetijske s pomočjo rekultivacije (Pogačnik in sod., 1995). Rekultivacija je odvisna od oddaljenosti, dostopnosti in oblike parcele ter pedogeoklimatskih dejavnikov (Corbelle Rico in sod., 2012). Poznamo več načinov rekultivacije, kot so požig zaraščene površine, ročno ali mehanično odstranjevanje lesne biomase in rekultiviranje s pomočjo živali (Vidrih in sod., 1996; Vodlan, 2006). Če preprečevanje in odpravljanje zaraščanja ni možno ali smiselno, je možno alternativno 
ekstenzivno kmetovanje $\mathrm{v}$ obliki manj intenzivne pridelave zelišč, dišavnic (npr. pridelava sivke na Krasu), različnih vrst jagodičja (npr. pridelava brinovih jagod na Krasu) (Cunder, 1998) ali drevesno-pašne dejanske rabe (Pogačnik in sod., 1995; Vidrih, 2010). V oddaljenih, težje dostopnih območjih lahko pogozdovanje služi za pridobivanje lesa, lov, rekreacijo ali kot naravovarstveno območje (Cunder, 1998; Cojzer, 2011; Corbelle Rico in sod., 2012). Pri oblikovanju kmetijske politike, ki bi preprečevala opuščanje kmetovanja, je potreben teritorialen in prostorski pristop (Renwick in sod., 2013). Zakonodaja se običajno razvija v smeri spodbujanja lokalnega gospodarstva (npr. združevanje kmetov, razvoj izdelkov $\mathrm{z}$ dodano vrednostjo), poenostavljanja spremembe lastništva, pravice do koriščenja zemljišča, milejše davčne politike, neposrednih plačil in pomoči pri odkupu pridelkov.
$\mathrm{V}$ prispevku nameravamo s pomočjo javno dostopnih prostorskih podatkov ugotoviti prostorsko razporeditev kmetijskih zemljišč v zaraščanju in kmetijskih zemljišč, poraslih z gozdnim drevjem po slovenskih občinah in statističnih regijah. Ugotoviti smo želeli tudi, kakšen je vpliv izbranih naravnih dejavnikov (naklon, nadmorska višina, ekspozicija, poplavnost, delež gozda) ter statusa upravljanja območja (NATURA 2000, parki in rezervati, območje z omejeni dejavniki, vodovarstveno območje, območje življenjskega prostora rjavega medveda) na razporeditev izbranih razredov dejanskih rab. V analizo smo vključili podatke o dejanski rabi zemljišč, kot je bila zaznana $\mathrm{v}$ času nastajanj tega prispevka.

\section{MATERIALI IN METODE}

\subsection{Prostorski sloji in opis območja raziskovanja}

Za potrebe prostorske analize smo v državnih ustanovah pridobili ustrezne prosto dostopne georeferencirane digitalne prostorske sloje (Preglednica 1, Slika 1).

Preglednica 1: Nabor in vir georeferenciranih digitalnih podatkovnih slojev, uporabljenih v prostorskih analizah kmetijskih zemljišč v zaraščanju v Sloveniji

Table 1: Dataset and source of georeferenced data used in spatial analysis of the abandonment of agricultural land in Slovenia

\begin{tabular}{|l|l|}
\hline Podatkovni prostorski sloj & Vir podatka \\
\hline Dejanska raba zemljišč (RABA) & $\begin{array}{l}\text { Ministrstvo za kmetijstvo, gozdarstvo in prehrano } \\
\text { (MKGP, 2011) }\end{array}$ \\
\hline $\begin{array}{l}\text { Območja z omejenimi dejavniki (OMD) } \\
\text { Državna meja }\end{array}$ & Geodetska uprava Republike Slovenije (GURS, 2011) \\
\hline Meje občin & \\
\hline Digitalni model višin 25mx25m (DMV) & Agencija Republike Slovenije za okolje (ARSO, 2011) \\
Ekološko pomembna območja (EPO) & \\
$\begin{array}{l}\text { Zavmočja Nature } 2000 \text { (NATURA) } \\
\text { Življenjski prostor rjavega medveda (ŽPRM) } \\
\text { Poplavna območja (PO) } \\
\text { Vodovarstvena območja (VVO) }\end{array}$ & \\
\hline Meje statističnih regij & Statistični urad Republike Slovenije (SURS, 2011) \\
\hline
\end{tabular}

Po definiciji iz določanja razredov dejanske rabe je kmetijsko zemljišče v zaraščanju (v nadaljevanju: raba 1410) zemljišče, ki se zarašča zaradi opustitve kmetovanja ali preredke obdelave zemljišč, kar je lahko posledica neugodnih naravnih razmer za kmetovanje (naklon, osončenost, nadmorska višina, lastnosti tal, itd.) ali socio-ekonomskih razlogov (starost in izobraženost lastnikov, velikost kmetije, itd.) (Slika 1c) (MKGP, 2012). Na njem se pojavlja invazivno in trnasto rastlinje ter drevesa in grmičevje različnih starosti, katerih pokrovnost je 20-75\%. Drevesa so majhna, mlada in posamično razporejena. Neobdelanih vinogradov in drugih trajnih nasadov ne uvrščamo $\mathrm{v}$ ta razred, dokler so na letalskih posnetkih (ortofoto) vidne vrste (MKGP, 2012). Kmetijsko zemljišče, poraslo z gozdnim drevjem ( $v$ nadaljevanju: raba 1800) je površina, porasla $\mathrm{s}$ travinjem, na kateri rastejo posamična gozdna drevesa oziroma grmi in se redno, 
vsaj enkrat letno, popase oziroma pokosi (Slika 1c). Rabo 1800 smo vključili $\mathrm{v}$ analizo, ker $\mathrm{v}$ primeru opuščanja kmetijske pridelave na teh zemljiščih predstavljajo izhodišče za zaraščanje. $\mathrm{V}$ primeru uveljavljanja neposrednih plačil so ta zemljišča uvrščena med kmetijska zemljišča. Pokrovnost travinja je vsaj $80 \%$, pokrovnost drevesnih krošenj oziroma grmov je manjša od $75 \%$ (MKGP, 2012).

V Sloveniji je bilo v letu 201125.278 ha rabe 1410, kar predstavlja $1,25 \%$ celotne površine države. Zemljišč rabe 1800 je bilo 9.496 ha, kar predstavlja 0,47\% celotne površine države (MKGP, 2011). Zemljišča rabe 1410 so razporejena po celotni Sloveniji z glavnino v osi od jugozahoda proti severovzhodu, medtem ko je zemljišč rabe 1800 največ $\mathrm{v}$ jugozahodnem delu države.

$\mathrm{V}$ razred dejanske rabe gozd (v nadaljevanju: raba 2000) spadajo zemljišča, porasla $\mathrm{z}$ gozdnim drevjem $\mathrm{v}$ obliki sestoja ali drugim gozdnim rastjem, ki zagotavlja katero koli funkcijo gozda. Med gozd se uvršča tudi zemljišča, poraščena z ruševjem (če je pokrovnost večja kot $75 \%$ ), površine, kjer je bila izvedena pomladitvena sečnja in so zato začasno brez drevja, poseke na trasah daljnovodov, cevovodov in smučarskih vlečnic, sanacije pogorišč, površine z mladimi drevesi, plantaže gozdnega drevja in gozdne drevesnice, ki so del gozda in jih na podlagi letalskih posnetkov (ortofoto) ne moremo posebej izločiti (MKGP, 2012). V razred gozd ne spadajo površine, poraščene $\mathrm{z}$ drevjem, kot so npr.: mestni parki in vrtovi (te se uvrščajo pod razred rabe 3000 pozidano in sorodno zemljišče), posamične skupine dreves, ki imajo manjšo površino kot $2.500 \mathrm{~m}^{2}$ in rekreacijska območja. Jase $\mathrm{v}$ gozdu se izločijo kot kmetijska zemljišča, če so večje od $5.000 \mathrm{~m}^{2}$. Izločajo se tudi manjše površine, če so ta zemljišča $v$ register kmetijskih gospodarstev vpisana kot GERK. Iz gozda so izločene ceste, ki so širše od $2 \mathrm{~m}$ in vodijo do naselij ali posameznih hiš (MKGP, 2012). Po evidenci MKGP je bilo v Sloveniji v času raziskave 1.210 .010 ha gozdov, kar predstavlja 59,89 \% površine države.
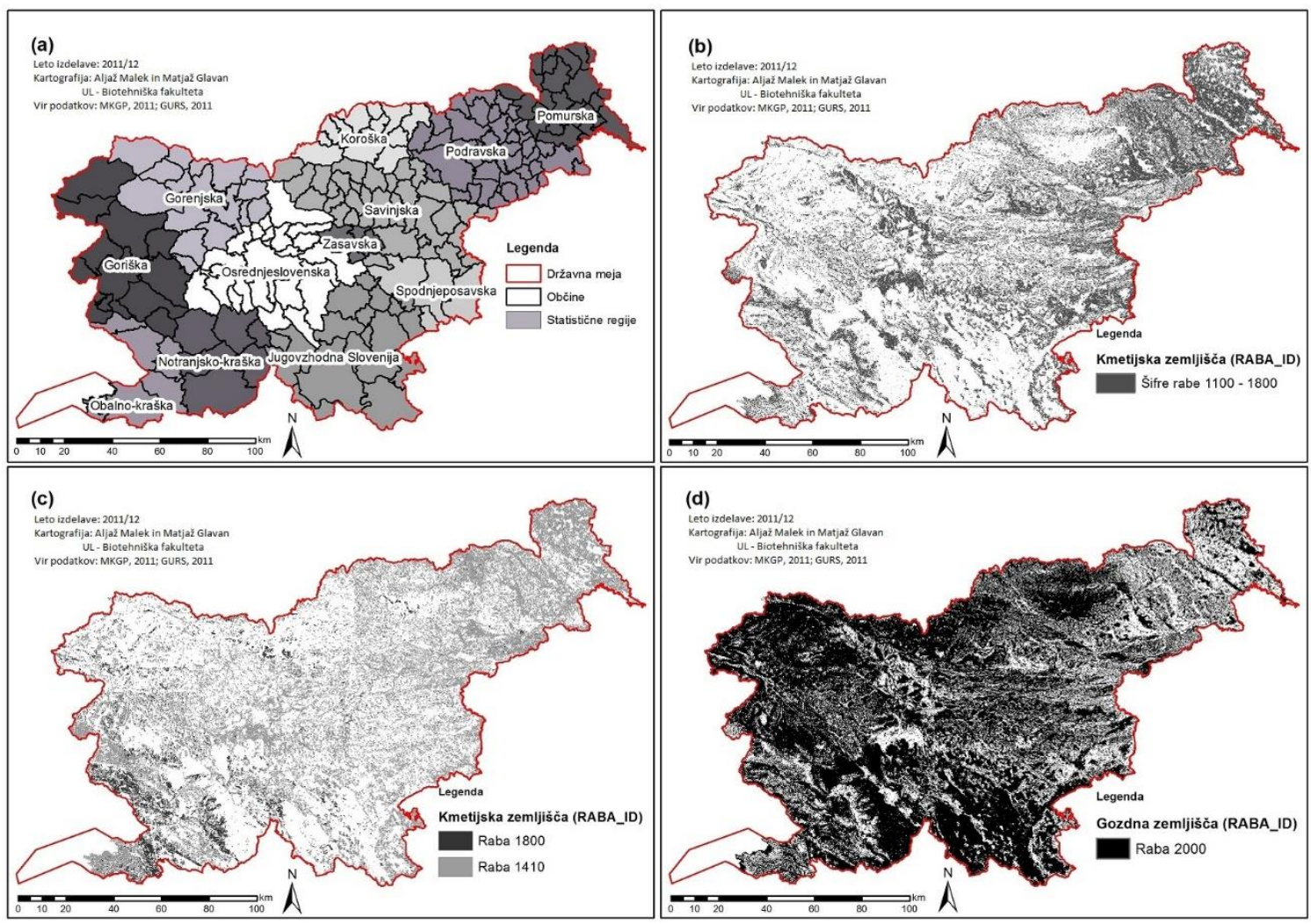

Slika 1: Prostorska razporeditev: (a) občin in statističnih regij, (b) združenih razredov kmetijske dejanske rabe od 1100 do 1800, (c) kmetijskih zemljišč $\mathrm{v}$ zaraščanju (1410) in kmetijskih zemljišč poraslih $\mathrm{z}$ gozdnim drevjem (1800) - meje poligonov so odebeljene za boljšo vidljivost, (d) gozda (razred rabe 2000) v Sloveniji

Figure 1: Spatial distribution of: (a) municipalities and statistical regions, (b) joined agricultural land use classes from1 100 to 1800 , (c) abandoned agricultural land use class (1410) and agricultural land use with forest trees class (1800) - polygon borders are made bold for better visibility, (d) forest (land use class 2000) in Slovenia 
Digitalni model višin (DMV) smo za potrebe analize razvrstili v 10 razredov nadmorskih višin oz. v 200 metrske višinske pasove (Slika 2a). Največji odstotek od celotne površine države predstavljajo višinski pas od 200,01 do 400,00 m (33,07\% površine države). Najmanjši odstotek od celotne površine države predstavljajo višinski pas od 1600,01 do $1800,00 \mathrm{~m}$ $(0,88 \%$ površine države). Razrede naklona smo razdelili po merilih za bonitiranje zemljišč na 8 razredov, kot jih določa Pravilnik o določanju in vodenju bonitete zemljišč (RS, 2008) (Slika 2b). Največji odstotek od celotne površine države predstavljajo območja $\mathrm{z}$ naklonom od 0 do $6 \%$ $(21,12 \%)$. Najmanjši odstotek predstavljajo območja $\mathrm{z}$ naklonom, večjim od $65 \%$ (7,29\%). Površino Slovenije smo razdelili na pet razredov ekspozicije površja (Slika 2c). V analizi smo uporabili prostorske podatke poplavnih območij (Slika 2d) redkih poplav z dogodki s povratno dobo deset (Q10) do dvajset (Q20) let in pogostih poplav z dogodki s povratno dobo dve (Q2) do pet (Q5) let. Območij redkih poplav je v Sloveniji 29.344 ha (1,45\% Slovenije), območij pogostih poplav je 6.422 ha $(0,32 \%$ Slovenije $)$.
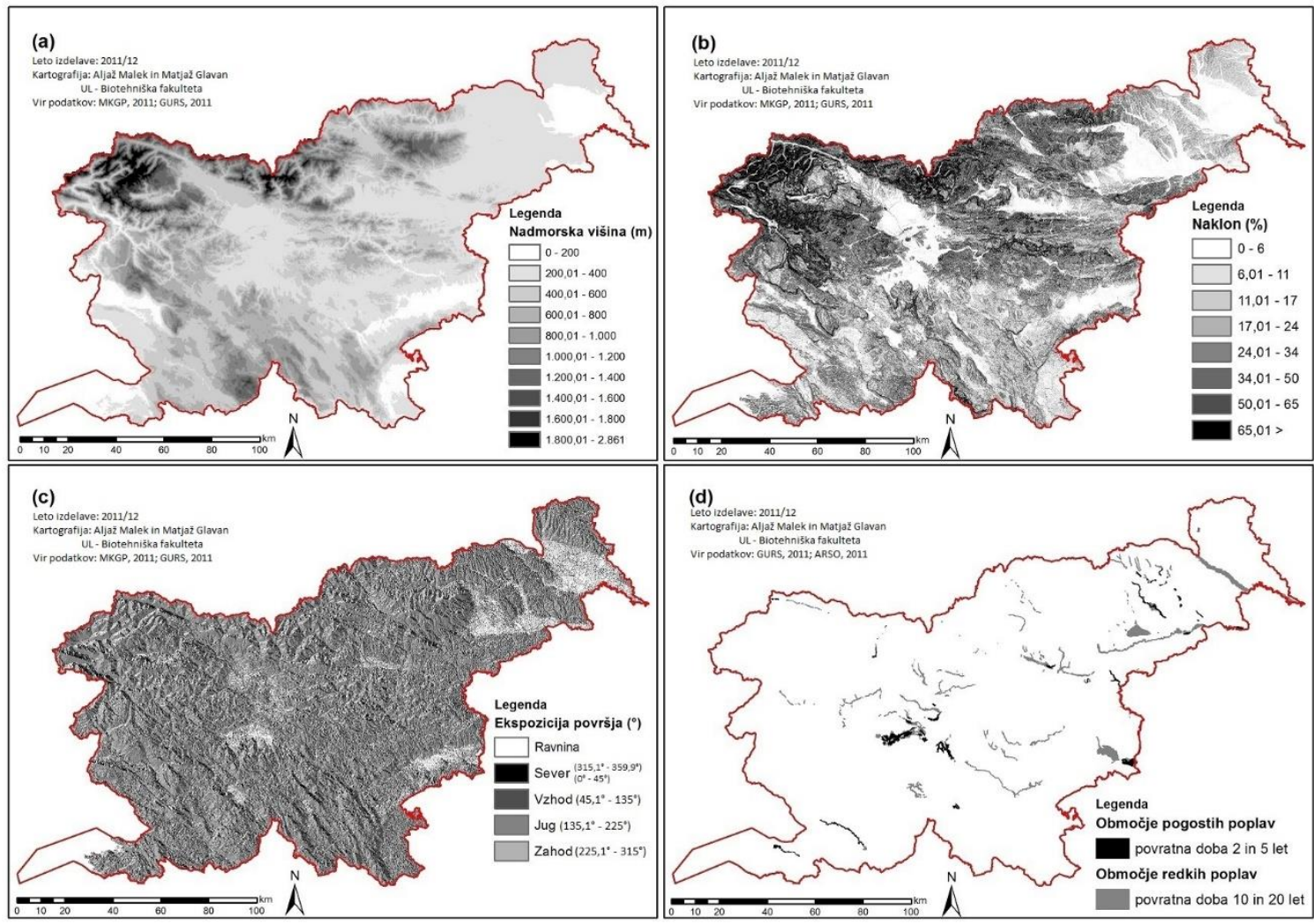

Slika 2: Prostorska razporeditev razredov (a) nadmorske višine, (b) naklon, (c) ekspozicija površja in (d) pogostost poplavljanja v Sloveniji

Figure 2: Spatial distribution of (a) altitude above sea level classes (m), (b) slope classes (\%), (c) surface exposition $\left({ }^{\circ}\right)$, and (d) flood areas in Slovenia

V analizo smo vključili območja petih izbranih upravljavskih statusov (Slika 3). Izbor je temeljil na: (1) območja so določena $\mathrm{v}$ zakonodaji; (2) območja so umeščena $\mathrm{v}$ prostor $\mathrm{z}$ jasnimi mejami; (3) režim upravljanja območij vpliva na kmetijsko dejavnost in odločanje lastnikov o vrsti dejanske rabe zemljišč. Ta območja so: (a) NATURA 2000; (b) zavarovana območja; (c) območja $\mathrm{z}$ omejenimi dejavniki za kmetijsko dejavnost; (d) vodovarstvena območja in (e) območje življenjskega prostora rjavega medveda. Območja NATURA 2000 so bila potrjena z Uredbo o posebnih varstvenih območjih (RS, 2004a) in jih delimo na območja, določena na podlagi direktive o habitatih SCI (79/409/EGS) in območja, določena na podlagi direktive o pticah - SPA (92/43/EGS) (Slika 3a). Prostorski podatkovni sloj zavarovanih območij narave prikazuje območja, ki so zavarovana po različnih predpisih o ohranjanju narave (Slika 3b). Zavarovana območja se po Zakonu o ohranjanju narave delijo na ožja zavarovana območja (naravni spomenik, strogi naravni rezervat in naravni rezervat) in širša zavarovana območja (narodni, regijski in krajinski park) (RS, 2004b). 


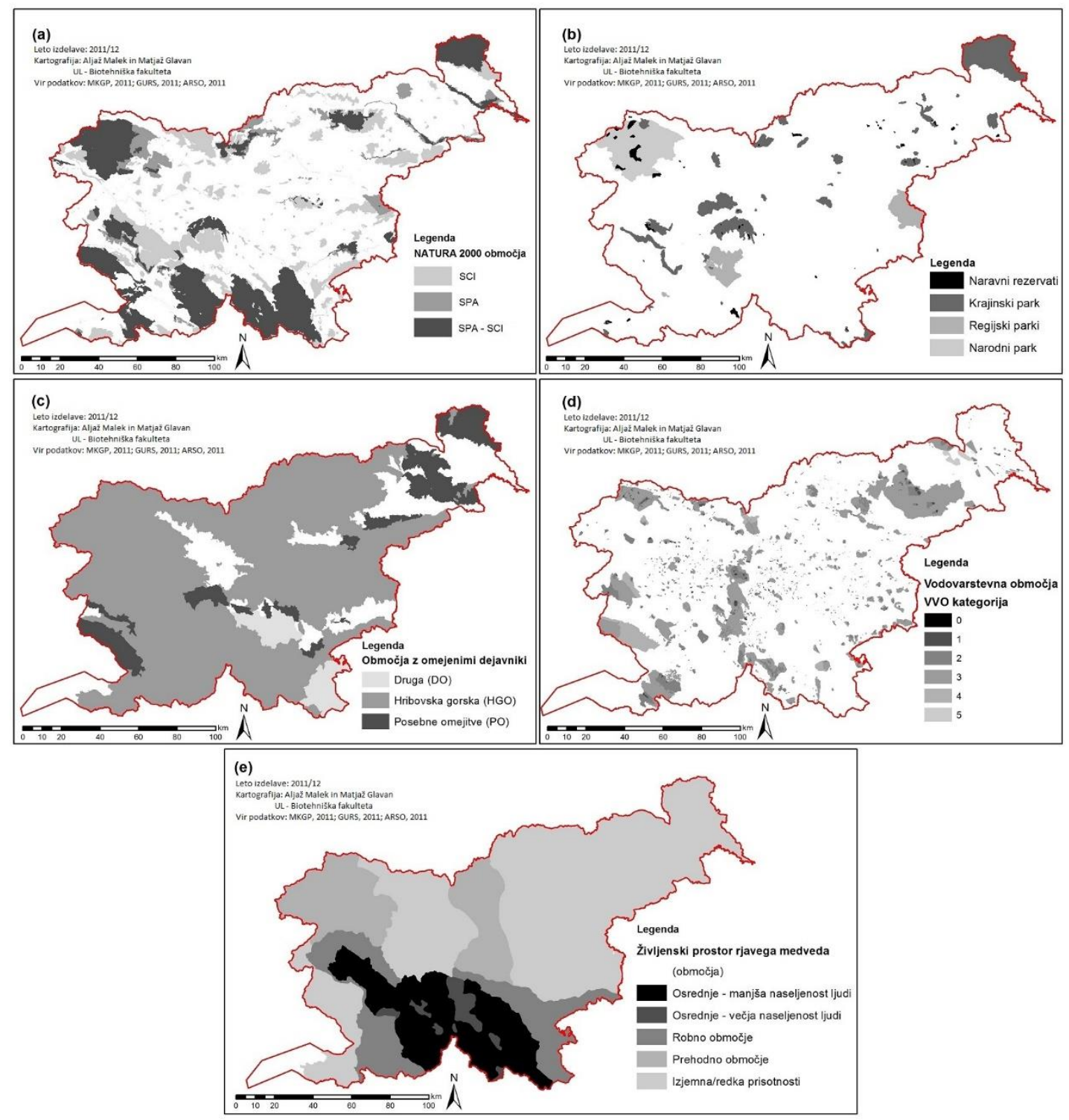

Slika 3: Prostorska razporeditev: (a) območij NATURA 2000, (b) območij nacionalnih, regijskih ali krajinskih parkov, (c) območij z omejenimi dejavniki za kmetijsko dejavnost, (d) vodovarstvenih območij in (e) območij življenjskega prostora rjavega medveda v Sloveniji

Figure 3: Spatial distribution of (a) NATURA 2000 areas, (b) national, regional or landscape parks areas, (c) naturally less favoured areas for agricultural activities, (d) water protection areas, and (e) areas of life environment of brown bear in Sloveni

Leta 2011 je bilo 286 območij Natura 2000 s skupno površino 720.286 ha, kar je predstavljalo $35,53 \%$ površine države (Slika 3a). Prostorski podatkovni sloj zavarovanih območij narave obsega 252.929 ha $(12,48 \%$ Slovenije) in prikazuje območja, ki so zavarovana po različnih predpisih o ohranjanju narave (Slika 3b). Območja z omejenimi dejavniki za kmetijsko dejavnost (OMD) obsegajo 1.751.251 ha $(86,38 \%)$ in se $\mathrm{v}$ prostorskem sloju delijo na hribovska gorska območja $\mathrm{v}$ obsegu 1.467 .573 ha $(72,39 \%)$, druga območja v obsegu 81.196 ha $(4,00 \%)$ in območja s posebnimi omejitvami v obsegu 202.482 ha $(9,99 \%)$ (RS, 2015) (Slika 3c). Vodovarstvena območja (VVO) v Sloveniji obsegajo 350.202 ha $(17,27 \%)$ in se glede na režim varovanja za zaščito vodnih virov delijo na državni nivo v obsegu 129.261 ha $(6,38 \%)$, občinski nivo v obsegu 216.160 ha $(10,66 \%)$ in vrelčni nivo $\mathrm{v}$ obsegu 4.781 ha $(0,24 \%)$ (Slika $3 \mathrm{~d})$. Območje življenjskega prostora rjavega medveda se deli na štiri dele (Slika 3e). Osrednje območje obsega 347.625 ha 
$(17,32 \%)$, od tega predstavlja 305.972 ha $(15,25 \%)$ območje manjše naseljenosti ljudi in 41.653 ha $(2,08 \%)$ območje gostejše naseljenosti ljudi. Robno območje obsega 255.662 ha $(12,74 \%)$, prehodno 308.523 ha $(15,37 \%)$, območje izjemne (redke) prisotnosti medveda pa obsega 1.095.003 ha (54,56 \%) (Slika 3e).

Pravilnik o razvrstitvi kmetijskih gospodarstev v območja z omejenimi možnostmi za kmetijsko dejavnost (OMD) določa tri vrste območij (RS, 2015) (Slika 3c). V hribovska gorska območja (HGO) uvrščamo območja, kjer je pridelava na zemljiščih omejena zaradi nadmorske višine in/ali naklona zemljišč na manjši nadmorski višini. Za druga območja $z$ omejenimi dejavniki (DO) so značilne tako neugodne naravne razmere (geologija, tla, konfiguracija terena, parcelna struktura) kot tudi socio-ekonomska in demografska struktura (odseljevanje, negativni prirast, brezposelnost, velikost kmetij). V območja s posebnimi omejitvami (PO) prištevamo območja, kjer se kmetovanje nadaljuje, da bi zagotovili ohranjanje ali izboljšanje okolja, ohranjanje življenjskega prostora na podeželju in varovanje turističnega potenciala območja.

VVO območja se glede na režim varovanja za zaščito vodnih virov delijo na državni, občinski in vrelčni nivo (Slika 3e). Nivoji se delijo še na kategorije varstvenih režimov (od 0 do 5). Najstrožji režim varovanja je $\mathrm{v}$ kategorijah 0,1 in 2. V 3. in 4. kategoriji je režim blažji. Kategorija 5 zajema le vrelčni nivo vodovarstvenih območij. Vodovarstvena območja državnega nivoja se določajo glede na Pravilnik o kriterijih za določitev vodovarstvenih območij (RS, 2004c), vodovarstvena območja občinskega in vrelčnega nivoja se določajo $\mathrm{z}$ odloki in medobčinskimi uradnimi vestniki $\mathrm{s}$ pripadajočimi strokovnimi podlagami. Kategorija varstvenega režima vpliva predvsem na način gnojenja kmetijskih zemljišč in uporabe fitofarmacevtskih sredstev (strožji režim - manjša uporaba gnojil in sredstev za varstvo rastlin), kar se odraža v obsegu pridelka in prihodkov.

Območje življenjskega prostora rjavega medveda se deli na pet delov: (a) osrednje območje - manjša naseljenost ljudi; (b) osrednje območje - območje gostejše naseljenosti ljudi; (c) robno območje; (d) prehodno in (e) območje izjemne (redke) prisotnosti medveda. Območja oz. cone opredeljuje Strategija upravljanja $\mathrm{z}$ rjavim medvedom v Sloveniji iz leta 2002, ki je vodilo za načrtovanje akcijskega načrta, za upravljanje z rjavim medvedom (MOP, 2002, 2007).

\subsection{Metodologija prostorske analize}

Prostorska analiza je bila opravljena $\mathrm{z}$ geografskim informacijskim sistemom Esri ArcGis 10.0. Iz podatkovnega sloja RABA smo za nadaljnjo uporabo pripravili sloje rabe 1410 , rabe 1800 in rabe 2000 . Urejanju površin novih slojev $\mathrm{v}$ atributnih tabelah je sledil njihov uvoz v MS Office Excel, kjer je sledila statistična analiza. Za ugotavljanje odvisnosti pojavljanja rabe 1410 in rabe 1800 od izbranih naravnih danosti (nadmorska višina in naklon) sta bila uporabljena regresijski model in Pearsonov koeficient korelacije (povezanost odstotka rabe 1410 in rabe 1800 z rabo 2000 na območju posameznih občin). Pri preučevanju razširjenosti rabe 1410 in rabe 1800 so bili uporabljeni odstotki določene rabe glede na celotno površino kmetijskih zemljišč $\mathrm{v}$ izbranem razredu nadmorske višine oz. naklona. Za ugotavljanje povezave med rabo 1410 in rabo 1800 ter rabo 2000 so bili uporabljeni odstotki rabe od površin občin.

\section{REZULTATI IN DISKUSIJA}

\subsection{Občine in statistične regije}

Zemljišča $\mathrm{z}$ rabo 1410 so razporejena po celi Sloveniji z glavnino v osi od jugozahoda proti severovzhodu. Glede na delež površine regije je raba 1410 najbolj razširjena v obalno-kraški statistični regiji in pomurski statistični regiji. Glavnina kmetijskih zemljišč rabe 1800 je v jugozahodnem delu države (obalno-kraška, goriška in notranjsko-kraška statistična regija) (Preglednica 2). 
Preglednica 2: Površina (ha) in odstotek (\%) zemljišč rabe 1410 (kmetijsko zemljišče $\mathrm{v}$ zaraščanju) in 1800 (kmetijsko zemljišče poraslo z gozdnim drevjem) glede na celotno površino in površino kmetijskih zemljišč (KZ) po statističnih regijah Slovenije

Table 2: Area (ha) and share (\%) of abandoned agricultural land class (1410) and agricultural land use with forest trees class (1800) in comparison to total and agricultural land area (KZ) in statistical regions in Slovenia

\begin{tabular}{|l|r|r|r|r|r|rrr|}
\hline \multirow{2}{*}{ Statistična regija } & \multicolumn{4}{|c|}{ Površina } \\
\cline { 2 - 10 } & območje & \multicolumn{1}{|c|}{ KZ } & \multicolumn{3}{|c|}{ Raba 1410 } & \multicolumn{3}{c|}{ Raba 1800 } \\
\cline { 2 - 10 } & \multicolumn{1}{c|}{ ha } & \multicolumn{1}{c|}{ ha } & \multicolumn{1}{c|}{ ha } & \% regije & \% KZ & \multicolumn{1}{c|}{ ha } & \% regije & \% KZ \\
\hline Gorenjska & 213.660 & 43.312 & 1.360 & 0,64 & 3,14 & 704 & 0,33 & 1,63 \\
\hline Goriška & 232.550 & 52.000 & 3.613 & 1,55 & 6,95 & 1.734 & 0,75 & 3,33 \\
\hline Jugovzhodna Slovenija & 267.509 & 69.891 & 2.842 & 1,06 & 4,07 & 679 & 0,25 & 0,97 \\
\hline Koroška & 104.080 & 24.351 & 737 & 0,71 & 3,03 & 205 & 0,20 & 0,84 \\
\hline Notranjsko-kraška & 145.634 & 37.685 & 1.275 & 0,88 & 3,38 & 1.789 & 1,23 & 4,75 \\
\hline Obalno-kraška & 104.445 & 36.083 & 3.072 & 2,94 & 8,51 & 3.270 & 3,13 & 9,06 \\
\hline Osrednjeslovenska & 255.496 & 80.372 & 2.570 & 1,01 & 3,20 & 513 & 0,20 & 0,64 \\
\hline Podravska & 216.967 & 107.897 & 3.550 & 1,64 & 3,29 & 162 & 0,07 & 0,15 \\
\hline Pomurska & 133.753 & 81.425 & 3.126 & 2,34 & 3,84 & 34 & 0,03 & 0,04 \\
\hline Savinjska & 238.398 & 86.021 & 1.800 & 0,76 & 2,09 & 294 & 0,12 & 0,34 \\
\hline Spodnjeposavska & 88.514 & 39.145 & 1.112 & 1,26 & 2,84 & 54 & 0,06 & 0,14 \\
\hline Zasavska & 26.375 & 7.602 & 222 & 0,84 & 2,91 & 57 & 0,22 & 0,75 \\
\hline Skupaj & $\mathbf{2 . 0 2 7 . 3 8 0}$ & $\mathbf{6 6 5 . 7 8 2}$ & $\mathbf{2 5 . 2 7 8}$ & $\mathbf{1 , 2 5}$ & $\mathbf{3 , 8 0}$ & $\mathbf{9 . 4 9 6}$ & $\mathbf{0 , 4 7}$ & $\mathbf{1 , 4 3}$ \\
\hline
\end{tabular}

Največ rabe 1410 je v delih regij (Kras, Brkini, Barje, Haloze, Slovenske gorice, Goričko), kjer ob sočasnih spremembah razmer na trgu dela in na kmetijskem trgu prihaja do neugodnih socio-ekonomskih razmer. Tudi v analizi ukrepov upravljanja progama Natura 2000 za sektor kmetijstva so kot enega pomembnih razlogov za zaraščanje in zmanjševanje biotske pestrosti navedli socio-ekonomske vidike (starost, bolezen, ni naslednika) (Žvikart in sod., 2013). Ob tem se kmetijstvo ni zmožno dovolj hitro prilagoditi npr. z lastniško strukturo ali velikostjo parcel. Pogosto je omejujoč faktor naravna danost (naklon, tla), zato je $\mathrm{v}$ takih razmerah edina možnost ekstenzifikacija pridelave. Obalno-kraška statistična regija predstavlja izredno priložnost za krepitev drevesno-pašnega sistema na že obstoječih kraških gmajnah in za njegovo uvedbo na širšem območju, po vzoru savan in dehes. O možnosti ekstenzivnega koriščenja manj zanimivih kmetijskih zemljišč ter njegovih prednostih ob omejenih naravnih danostih za intenzivno kmetijsko pridelavo piše več avtorjev (Knap, 2008; Eler in sod., 2008; Vidrih, 2010). V regijah in občinah, kjer je zaraščanja manj, bi bilo na podlagi sosednje vrste dejanske rabe in lastnosti zemljišč treba razmisliti, $\mathrm{v}$ katero smer razvijati nadaljnjo dejansko rabo teh zemljǐ̌č. Ena od možnosti je sečnja lesne biomase iz zaraščenih območij in predelava v sekance ali pelete (Vodlan, 2006; Humar, 2008).

\subsection{Naravni dejavniki}

Statistična analiza je pokazala, da imajo glede na površino največji odstotek rabe 2000 občine Osilnica (3.191 ha, 88,11\%), Črna na Koroškem (13.605 ha, $87,23 \%)$, Dolenjske Toplice (9.459 ha, 85,83\%), Kostel (4.769 ha, 85,03\%) in Lovrenc na Pohorju (7.160 ha, 84,80\%). Zemljišča rabe 1410 in $1800 \mathrm{v}$ teh občinah predstavljajo manj kot $1 \%$ površine občine. S pomočjo Pearsonovega koeficienta korelacije smo ugotavljali povezanost deležev rabe 1400 in rabe $1800 \mathrm{z}$ rabo 2000 (Slika 4). Med rabama 1410 in 2000 (Pearsonov koeficient korelacije: - 0,3) in med rabama 1800 in 2000 (Pearsonov koeficient korelacije: 0,26) ni opaznih izrazitih vzorcev (Slika 4). Občine na JZ države Z večjim odstotkom gozda imajo večji odstotek rabe 1800. Z izvajanjem kmetijske dejavnosti (paša, občasna sečnja in mulčenje) se slednja počasneje ali sploh ne zaraščajo, že obstoječa starejša drevesa rastejo naprej, medtem ko se podrast stalno odstranjuje. Vendar vzdrževanja rabe 1800 ni možno izvajati strojno, zato so pašne živali nujno potrebne. Vzreja pašnih živali zahteva stalno fizično prisotnost pastirja ali dobro varovano ogrado, ki preprečuje dostop divjim zverem, ki na območje rabe 1800 dostopajo iz sosednjih gozdov (Černe in sod., 2010). Prav škodni dogodki kot posledica napada divjih živali (volkovi, medvedi) so glavni razlog opuščanja pašništva na območju obalnokraške in notranjsko-kraške regije (Pogačnik in sod., 2006). 


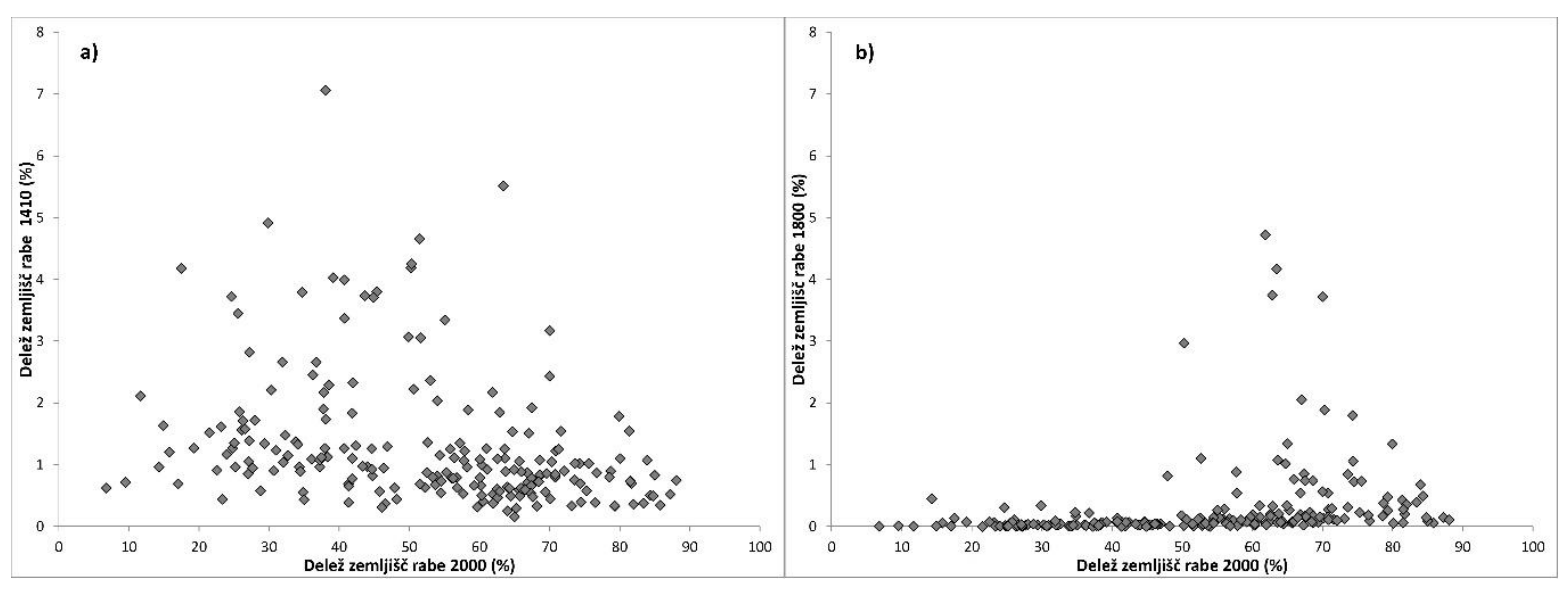

Slika 4: Razsevni grafikon predstavlja povezanost razredov dejanske rabe (a) kmetijska zemljišča v zaraščanju (1410) in (b) kmetijska zemljišča porasla z gozdnim drevjem (1800) z odstotkom gozdne rabe (2000) po občinah

Figure 4: Scattered chart presenting connections between classes of actual land use (a) abandoned agricultural land (1410) and (b) agricultural land with forest trees class (1800) and forest (2000) by municipality

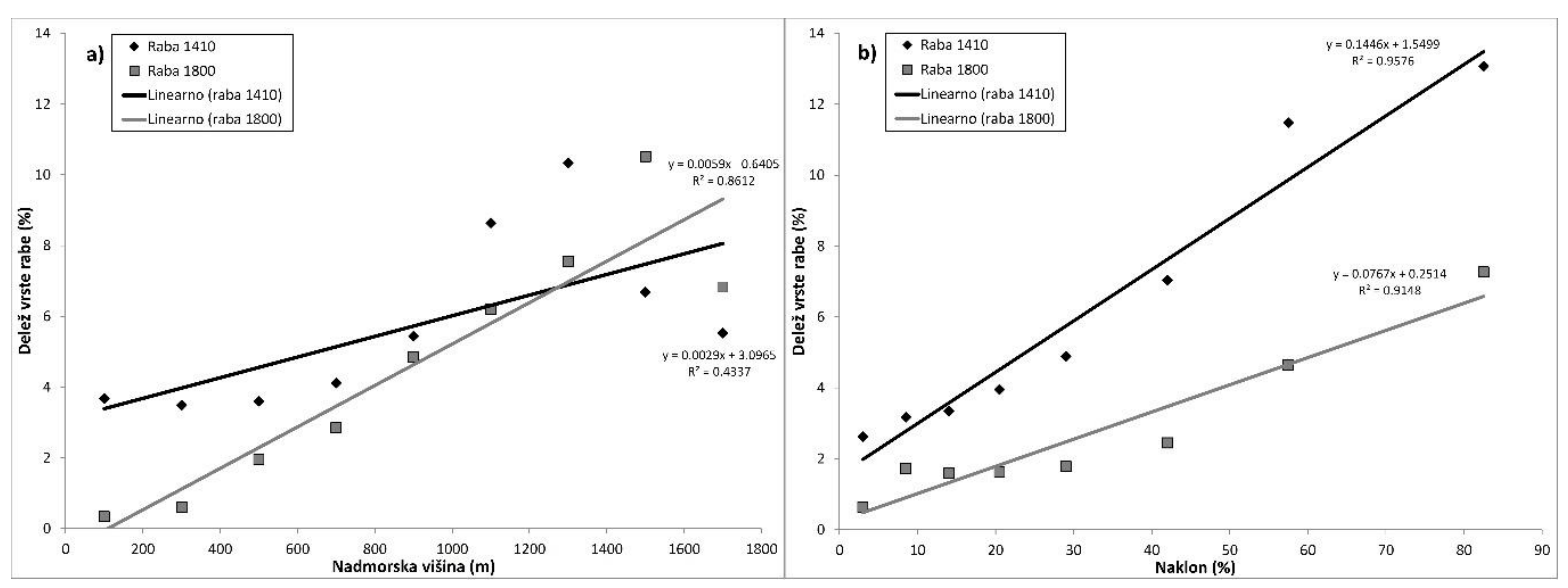

Slika 5: Primerjava deležev razredov dejanske rabe kmetijsko zemljišče v zaraščanju (1410) in kmetijsko zemljišče poraslo z gozdnim drevjem (1800) v odvisnosti od (a) nadmorske višine in (b) naklon po regresijskem modelu

Figure 5: Comparison between shares of actual land use classes of abandoned agricultural land (1410) and agricultural land with forest trees (1800) in dependence from (a) altitude above sea level and (b) slope by regression model

Ugotavljali smo, kako se $\mathrm{z}$ nadmorsko višino in naklonom spreminja delež posameznih razredov rabe 1410 in rabe 1800 . Uporabili smo regresijski model (Slika 5). Opazovan je bil odstotek rabe 1410 in 1800 od vseh in samo od kmetijskih zemljišč. V primeru upoštevanja celotne površine območja posameznega višinskega pasu se $\mathrm{z}$ večanjem nadmorske višine in naklona odstotek kmetijskih površin in s tem tudi rabe 1410 in 1800 zmanjšuje (Preglednica 3). V povprečju se odstotek zemljišč rabe 1410 in 1800 , glede na odstotek kmetijskih zemljišč, na vsakih 100 m nadmorske višine poveča za $0,29 \%$ in $0,59 \%$. V povprečju se odstotek zemljišč rabe 1410 in 1800 , s povečanjem naklona za $10 \%$, poveča za $1,5 \%$ in $0,8 \%$. Rezultati naše analize kažejo, da imata nadmorska višina in naklona vpliv na zaraščanje in se ujema $\mathrm{z}$ ugotovitvami drugih raziskav (Poyatos in sod., 2003; Hočevar in sod., 2004; Gellrich in Zimmermann, 2007, Ketiš in sod., 2014). Rezultat analize vpliva nadmorske višine in naklona nakazuje na povečanje površin rabe 1410 in $1800 \mathrm{v}$ primeru opuščanja kmetijske obdelave v obliki paše ali košnje strmih travnikov $v$ hribovitih predelih Slovenije. Še posebej izrazit je pojav v hribovsko-gorskem okolju, kjer opažajo upad populacije gozdnih kur zaradi zaraščanja gozdih jas, gorskih pašnikov in gozdnih robov, ki zaradi oddaljenosti niso več zanimivi za obdelavo (Kus Veenvliet, 2012). Kmetijska politika se zaveda vpliva opuščanja kmetijskih zemljišč, zato v okviru Programa razvoja podeželja Republika Slovenija 
(2014-2020) namenja neposredna plačila za košnjo habitatnih travnikov na naklonih, večjih od $50 \%$.

Iz podatkov (Preglednica 3) je razvidno, da so severne in zahodne osojne lege manj ugodne za kmetovanje, kar privede do opuščanja in vodi $v$ zaraščanje. Delno na večji odstotek zaraščanja vpliva tudi relief in smer poteka gorskih grebenov $\mathrm{v}$ Sloveniji, ki marsikje potekajo od severozahoda protu jugovzhodu in so na severnih in zahodnih legah bolj strmi ter s tem manj primerni za kmetijstvo. Zemljišča zahodnih in južnih leg na manjših nadmorskih višinah do 400 metrov imajo dober potencial za nadaljnjo, tudi bolj intenzivno kmetijsko pridelavo, kot so vinogradništvo in sadjarstvo ter oljkarstvo v Slovenski Istri in Goriških Brdih. Rabe 1800 se večinoma pojavljajo v jugozahodni Sloveniji, na območjih apnenčastih, dolomitnih in flišnih kamnin. Brez prisotnosti človekovega delovanja bi jih prekrival gozd s ekonomsko manj zanimivimi termofilnimi vrstami, ki so prilagojene tudi sušnim razmeram. Kmetovalci so jih zato izkoristili kot površine $\mathrm{s}$ kombiniranim gozdno-pašnim sistemov. Če teh površin ne vzdržujemo z redno pašo, se lahko hitro zarastejo $\mathrm{z}$ grmovno zarastjo in postanejo neprehodne. Večina teh površin je $\mathrm{z}$ obstoječo pašno rabo dosega svoj maksimalen izkoristek (Vidrih, 2005).

Površin rabe 1400 je glede na odstotek razreda in odstotek kmetijskih zemljišč več na območjih pogostih kot redkih poplav (Preglednica 3). Analiza je pokazala večji vpliv poplavnih območij na rabo 1410 kot na rabo 1800. Manjši vpliv na rabo 1800 izhaja iz dejstva, da je večina te rabe na specifičnih lokacijah, kjer se zaradi matične podlage (apnenec) in topografije (naklon) poplave ne pojavljajo. To potrjuje tudi majhen obseg (48 ha) teh zemljišč na poplavnih območjih. Poplavljanje posredno vpliva na zaraščanje kmetijskih zemljišč, saj lahko redne poplave otežujejo proces kmetovanja in zmanjšujejo pridelek. To lahko na mokrotnih travnikih in mokriščih (Cerkniško polje, Ljubljansko barje), privede do zmanjšanja rastlinske in živalske pestrosti, ki se najbolj očitno odrazi v številu ptic vlažnih travnikov (Žgavec in sod., 2013; Bordjan in Bordjan, 2014). 
Preglednica 3: Površine (ha) in odstotek (\%) rab kmetijsko zemljišče $\mathrm{v}$ zaraščanju (1410) in kmetijsko zemljišče poraslo z gozdnim drevjem (1800) v različnih razredih (a) nadmorskih višin (m), (b) naklon (\%), (c) ekspozicije površja $\left({ }^{\circ}\right)$ in (d) pogostosti poplav glede na površino kmetijskih zemljišč (KZ)

Table 3: Area (ha) and share (\%) of abandoned agricultural land use class (1410) and agricultural land use with forest trees class (1800) in different classes of (a) altitude above sea level classes (m), (b) slope classes (\%), (c) solar radiation exposition $\left({ }^{\circ}\right)$, and (d) flood areas in comparison to total area of agricultural land use (KZ)

\begin{tabular}{|c|c|c|c|c|c|c|c|c|}
\hline & \multicolumn{8}{|c|}{ Površina } \\
\hline & \multirow{2}{*}{$\begin{array}{c}\text { območje } \\
\text { ha }\end{array}$} & \multirow{2}{*}{$\frac{\mathrm{KZ}}{\mathrm{ha}}$} & \multicolumn{3}{|c|}{ raba 1410} & \multicolumn{3}{|c|}{ raba 1800} \\
\hline & & & ha & $\%$ razreda & $\% \mathrm{KZ}$ & ha & $\%$ razreda & $\% \mathrm{KZ}$ \\
\hline \multicolumn{9}{|c|}{ (a) Razredi nadmorske višine (m) } \\
\hline $0-200$ & 180.280 & 103.525 & 3.803 & 2,11 & 3,67 & 347 & 0,19 & 0,33 \\
\hline $200,01-400$ & 670.932 & 319.051 & 11.127 & 1,66 & 3,49 & 1.923 & 0,29 & 0,60 \\
\hline $400,01-600$ & 472.631 & 134.435 & 4.841 & 1,02 & 3,60 & 2.620 & 0,55 & 1,95 \\
\hline $600,01-800$ & 308.479 & 62.029 & 2.554 & 0,83 & 4,12 & 1.767 & 0,57 & 2,85 \\
\hline $800,01-1000$ & 168.112 & 24.142 & 1.312 & 0,78 & 5,43 & 1.169 & 0,70 & 4,84 \\
\hline $1000,01-1200$ & 95.741 & 7.621 & 659 & 0,69 & 8,64 & 472 & 0,49 & 6,20 \\
\hline $1200,01-1400$ & 61.972 & 4.298 & 444 & 0,72 & 10,34 & 325 & 0,52 & 7,56 \\
\hline $1400,01-1600$ & 31.449 & 5.047 & 337 & 1,07 & 6,69 & 531 & 1,69 & 10,52 \\
\hline $1600,01-1800$ & 17.768 & 3.235 & 179 & 1,01 & 5,53 & 221 & 1,24 & 6,83 \\
\hline $1800,01>$ & 19.927 & 2.302 & 59 & 0,30 & 2,58 & 120 & 0,60 & 5,22 \\
\hline Skupaj & 2.027.293 & 665.685 & 25.316 & 1,25 & $\mathbf{3 , 8 0}$ & 9.495 & 0,47 & 1,43 \\
\hline \multicolumn{9}{|l|}{ (b) Naklon (\%) } \\
\hline $0-6$ & 428.089 & 265.174 & 6.947 & 1,62 & 2,62 & 1.665 & 0,39 & 0,63 \\
\hline $6,01-11$ & 191.912 & 83.824 & 2.660 & 1,39 & 3,17 & 1.448 & 0,75 & 1,73 \\
\hline $11,01-17$ & 228.292 & 89.362 & 2.989 & 1,31 & 3,35 & 1.432 & 0,63 & 1,60 \\
\hline $17,01-24$ & 247.958 & 82.288 & 3.254 & 1,31 & 3,95 & 1.333 & 0,54 & 1,62 \\
\hline $24,01-34$ & 300.696 & 77.089 & 3.770 & 1,25 & 4,89 & 1.374 & 0,46 & 1,78 \\
\hline $34,01-50$ & 315.478 & 49.780 & 3.501 & 1,11 & 7,03 & 1.218 & 0,39 & 2,45 \\
\hline $50,01-65$ & 167.137 & 11.315 & 1.299 & 0,78 & 11,48 & 526 & 0,31 & 4,65 \\
\hline $65,01>$ & 147.731 & 6.852 & 896 & 0,61 & 13,07 & 498 & 0,34 & 7,27 \\
\hline Skupaj & 2.027.293 & 665.685 & 25.316 & 1,25 & 3,80 & 9.495 & 0,47 & 1,43 \\
\hline \multicolumn{9}{|c|}{ (c) Razredi ekspozicije površja () } \\
\hline Sever & 436.290 & 96.624 & 4.116 & 0,94 & 4,26 & 1.382 & 0,32 & 1,43 \\
\hline Vzhod & 483.991 & 153.663 & 5.800 & 1,20 & 3,77 & 1.925 & 0,40 & 1,25 \\
\hline Jug & 532.092 & 198.361 & 7.918 & 1,49 & 3,99 & 3.657 & 0,69 & 1,84 \\
\hline Zahod & 445.154 & 126.822 & 5.445 & 1,22 & 4,29 & 2.368 & 0,53 & 1,87 \\
\hline Ravnina & 129.766 & 90.214 & 2.037 & 1,57 & 2,26 & 163 & 0,13 & 0,18 \\
\hline Skupaj & 2.027 .293 & 665.685 & 25.316 & 1,25 & $\mathbf{3 , 8 0}$ & 9.495 & 0,47 & 1,43 \\
\hline \multicolumn{9}{|c|}{ (d) Razredi pogostosti poplav } \\
\hline Redke poplave & 29.344 & 20.496 & 803 & 2,74 & 3,92 & 44 & 0,15 & 0,21 \\
\hline Pogoste poplave & 6.422 & 4.984 & 209 & 3,25 & 4,19 & 4 & 0,06 & 0,07 \\
\hline Skupaj & 35.766 & 25.480 & 1.012 & 2,83 & $\mathbf{3 , 9 7}$ & 48 & 0,13 & 0,19 \\
\hline
\end{tabular}

Opomba: Zaradi uporabe rastrskih slojev v izračunu je skupna površina Slovenije nekoliko manjša.

\subsection{Dejavniki upravljanja območij}

Poudariti je treba, da je vpliv upravljavskega statusa območja na zaraščanje težje ovrednotiti, saj se različni statusi prostorsko prekrivajo. Iz analize je razvidno, da sta odstotka površin rabe 1410 in rabe 1800 glede na površino območja različno zastopana znotraj in zunaj območij. Glede na odstotek kmetijskih zemljišč na območjih je površina rab 1410 in 1800 večja znotraj kot zunaj obravnavanih območij (Preglednica 4). Upravljavski status območja lahko vpliva tako na zaraščanje kot na preprečevanje slednjega. Nekatera območja Natura 2000 so opredeljena kot kmetijske krajine. Različne raziskave potrjujejo, da opuščanje kmetijske dejavnosti negativno vpliva na populacije 
vrst, ki so od nje odvisne (MacDonald in sod., 2000; Kraj in Koren, 2011; Miličić in sod., 2011; Žgavec in sod., 2013; Žvikart in sod., 2013; Bordjan in Bordjan, 2014). Vpliv upravljavskega statusa območja ni omejen le na območje izvajanja, temveč tudi na njegovo neposredno okolico. Diaz in sodelavci (2011) ugotavljajo, da je zaraščanja več $\mathrm{v}$ bližini narodnih parkov, kar je posledica vzpostavljanja prvotne vegetacije.

Območja Nature 2000 in različne oblike parkov lahko z režimi upravljanja ali kmetijsko-okoljsko podnebnih plačil vplivajo na intenzivnost obdelave (npr. čas ali število košenj) in način kmetovanja (konvencionalno, integrirano, ekološko) (Žgavec in sod., 2013; Žvikart in sod., 2013). Zemljišča so lahko zaradi omejitev in okoljskih ukrepov manj produktivna in stroški vloženega dela in materiala večji, kar lahko privede do opuščanja kmetijske dejavnosti in posledično do zaraščanja (Glavan in Pintar, 2013). Območja Nature 2000 in parkov lahko ob primernem upravljanju pripomorejo $\mathrm{k}$ varovanju zaščitenega tipa krajine in tako vplivajo na preprečevanje zaraščanja kmetijskih zemljišč, a je za to potrebna kmetijska obdelava in pridelava (Knap, 2008; Gutman, 2011; Pogačnik, 2011; Miličić, 2011; Kus Veenvliet, 2012; Žgavec in sod., 2013). Na varovanih območjih, ki ležijo na izjemno dobrih tleh in legah, je opaziti trend intenziviranja obdelave in odpravljanja grmovne in drevesne zarasti, kar ima lahko kvarne posledice za biodiverziteto (Žgavec in sod., 2013; Žvikart in sod., 2013; Glavan in sod., 2015). Le vključevanje in izobraževanje kmetov ter sprememba odnosa nacionalne okoljske politike do kmetov bosta omogočila varovanje habitatov kulturne krajine.

Preglednica 4: Površine (ha) in delež (\%) razredov dejanske rabe (a) kmetijsko zemljišče v zaraščanju (1410) in (b) kmetijsko zemljišče poraslo z gozdnim drevjem (1800) na območjih z in brez izbranega upravljavskega statusa ter glede na površino območja in kmetijskih zemljišč (KZ)

Table 4: Area (ha) and share (\%) of actual land use classes (a) abandoned agricultural land (1410) and (b) agricultural land with forest trees (1800) in the areas with and without selected management status in comparison to total area and area of agricultural land (KZ)

\begin{tabular}{|c|c|c|c|c|c|c|c|c|}
\hline \multirow{3}{*}{ Območje } & \multicolumn{8}{|c|}{ Površina } \\
\hline & \multirow{2}{*}{$\begin{array}{c}\text { območje } \\
\text { ha }\end{array}$} & \multirow{2}{*}{$\begin{array}{c}\mathrm{KZ} \\
\text { ha }\end{array}$} & \multicolumn{3}{|c|}{$\mathrm{Z}$ upravljavskim statusom } & \multicolumn{3}{|c|}{$\begin{array}{c}\text { Brez upravljavskega } \\
\text { statusa }\end{array}$} \\
\hline & & & ha & $\begin{array}{c}\% \\
\text { območja }\end{array}$ & $\% \mathrm{KZ}$ & ha & $\begin{array}{c}\% \\
\text { območja } \\
\end{array}$ & $\% \mathrm{KZ}$ \\
\hline \multicolumn{9}{|l|}{ (a) Raba 1410} \\
\hline Natura 2000 & 720.286 & 158.011 & 9.478 & 1,32 & 6,00 & 15.800 & 1,21 & 3,11 \\
\hline $\begin{array}{l}\text { Območja z omejenimi } \\
\text { dejavniki }\end{array}$ & 1.751 .251 & 506.082 & 21.387 & 1,22 & 4,23 & 3.891 & 1,41 & 2,44 \\
\hline Življenjski prostor medveda* & 2.006 .813 & 665.588 & 24.884 & 1,24 & 3,74 & - & - & \\
\hline Narodni park & 83.808 & 8.913 & 731 & 0,88 & 8,25 & 24.543 & 1,26 & 3,74 \\
\hline Regijski parki & 43.442 & 16.113 & 509 & 1,17 & 3,16 & 24.770 & 1,25 & 3,81 \\
\hline Krajinski parki & 117.004 & 47.708 & 2.534 & 2,17 & 5,31 & 22.744 & 1,19 & 3,68 \\
\hline Naravni rezervati & 8.675 & 1.132 & 95 & 1,1 & 8,42 & 25.183 & 1,25 & 3,79 \\
\hline Vodovarstvena območja & 350.202 & 106.954 & 4.776 & 1,36 & 4,47 & 20.502 & 1,22 & 3,67 \\
\hline \multicolumn{9}{|l|}{ (b) Raba 1800} \\
\hline Natura 2000 & 720.286 & 158.011 & 6.065 & 0,84 & 3,84 & 3.430 & 0,26 & 0,68 \\
\hline $\begin{array}{l}\text { Območja z omejenimi } \\
\text { dejavniki }\end{array}$ & 1.751 .251 & 506.082 & 9.380 & 0,54 & 1,85 & 116 & 0,04 & 0,07 \\
\hline Življenjski prostor medveda* & 2.006 .813 & 665.588 & 9.403 & 0,47 & 1,41 & - & - & \\
\hline Narodni park & 83.808 & 8.913 & 428 & 0,51 & 4,81 & 9.067 & 0,47 & 1,38 \\
\hline Regijski parki & 43.442 & 16.113 & 143 & 0,33 & 0,89 & 9.352 & 0,47 & 1,44 \\
\hline Krajinski parki & 117.004 & 47.708 & 236 & 0,20 & 0,49 & 9.260 & 0,48 & 1,50 \\
\hline Naravni rezervati & 8.675 & 1.132 & 22 & 0,25 & 1,92 & 9.474 & 0,47 & 1,43 \\
\hline Vodovarstvena območja & 350.202 & 106.954 & 3.462 & 0,99 & 3,24 & 6.033 & 0,36 & 1,08 \\
\hline
\end{tabular}

* Življenjski prostor rjavega medveda je določen na celotnem ozemlju Republike Slovenije. 
Prisotnost rjavega medveda in njegovo povzročanje gospodarske škode lahko otežujeta rejo živali na prostem, predvsem rejo drobnice. Rjavi medved je zelo domač $\mathrm{V}$ zaraščajočih in opuščenih kmetijskih površinah, ki se marsikje zaradi intenzivnega zaraščanja širijo do urbanih naselij in kmetijskih površin v okolici (Jarni, 2011). Zato je akcijski načrt za upravljanje z rjavim medvedom predvidel intenzivno čiščenje zaraščajočih površin v okolici naselij (MOP, 2007). Prav gotovo bo morala kmetijska politika slediti zavezam, zapisanim v zakonu o kmetijskih zemljiščih, in nameniti finančna sredstva za odpravljanje zaraščanja.

Največji delež zemljišč rabe 1410 je glede na celotno površino OMD na območjih PO in glede na površino kmetijskih zemljišč na območjih DO (Preglednica 5). Odstotek zemljišč rabe 1800 je glede na površino območja največji na območjih s posebnimi omejitvami in glede na površino kmetijskih zemljišč na hribovskih gorskih območjih (Preglednica 5). Največje površine in velik odstotek zaraščanja na HGO so posledica tega, da ta območja obsegajo skoraj $75 \%$ države in zemljišča na večjih nadmorskih višinah ter večjih naklonih. Slednja naravna dejavnika imata izrazit vpliv na odločanje lastnikov zemljišč o obdelavi (Slika 5). Tipi OMD so glede na odstotke med seboj dokaj izenačeni. Neposredna plačila za OMD so bila uvedena $\mathrm{z}$ namenom blaženja vplivov neugodnih razmer za kmetovanje (nadmorska višina, naklon, kraška skalovitost in razgibanost terena ter poplavnih območij), $\mathrm{s}$ čimer se preprečuje opuščanje kmetovanja. S sistemom točkovanja, ki ga je pripravil Kmetijski inštitut Slovenije, je to prostorsko in analitsko en od najnatančneje dodelanih ukrepov skupne kmetijske politike v Sloveniji. Pri določanju zunanjih mej območij se lahko poleg naravnih danosti upošteva še demografske razmere (odseljevanje, negativni prirast, brezposelnost, velikost kmetij). Kljub temu, da se ob predstavitvi ukrepa OMD pogosto navaja ugodne vplive na preprečevanje zaraščanja, so v strokovni literaturi analize vpliva ukrepa na nivoju kmetij redke. Obstoječi študiji, ki obravnavata kmetijsko-okoljske ukrepe v okviru Programa razvoja podeželja (PRP) navajata, da na intenziteto obdelave in sestavo travne ruše močno vplivajo socio-ekonomski dejavniki, kot sta starost in izobrazba kmeta ter premajhna finančna vrednost neposrednih plačil, ki ne spodbujajo $\mathrm{k}$ vključitvi $\mathrm{v}$ ukrepe (Žgavec in sod., 2013; Ketiš in sod., 2016). Lastniki oz. obdelovalci zemljišč se za vključitev v OMD-ukrepe odločajo prostovoljno in za vsako parcelo pred uveljavljanjem ukrepa pretehtajo ekonomsko upravičenost obdelave. Razlogi za opuščanje ali nadaljevanje obdelave ne vključujejo le neposrednih plačil, temveč tudi pridelek na parceli, stroške, nastale z obdelavo, čas, potreben za vzdrževanje, dostopnost, možnost strojne obdelave. Če le en od teh dejavnikov ne izkazuje pozitivnega izida, lahko to vodi $\mathrm{v}$ opustitev obdelave in zaraščanje parcele. 
Preglednica 5: Površine (ha) in odstotek (\%) zemljišč dejanske rabe kmetijsko zemljišče v zaraščanju (1410) in kmetijsko zemljišče poraslo z gozdnim drevjem (1800) znotraj območij (a) Natura 2000, (b) varovanih narodnih, regijskih in krajinskih parkov ter naravnih rezervatov, (c) življenjskega prostora rjavega medveda, (d) z omejenimi dejavniki in (e) vodovarstvenih območij glede na površino območja in kmetijskih zemljišč (KZ)

Table 5: Area (ha) and share (\%) of actual land use abandoned agricultural land (1410) and agricultural land with forest trees (1800) within the areas of (a) Natura 2000, (b) national, regional or landscape parks, (c) life environment of brown bear, (d) naturally less favoured areas for agricultural activities and (e) water protection areas in comparison to total area and area of agricultural land (KZ)

\begin{tabular}{|c|c|c|c|c|c|c|c|c|}
\hline \multirow{3}{*}{ Območja } & \multicolumn{8}{|c|}{ Površina } \\
\hline & \multirow{2}{*}{$\begin{array}{c}\text { območja } \\
\text { ha }\end{array}$} & \multirow{2}{*}{$\begin{array}{c}\text { KZ } \\
\text { ha }\end{array}$} & \multicolumn{3}{|c|}{ raba 1400} & \multicolumn{3}{|c|}{ raba 1800} \\
\hline & & & ha & $\begin{array}{c}\% \\
\text { območja }\end{array}$ & $\% \mathrm{KZ}$ & ha & $\begin{array}{c}\% \\
\text { območja }\end{array}$ & $\% \mathrm{KZ}$ \\
\hline \multicolumn{9}{|l|}{ (a) Natura 2000} \\
\hline $\begin{array}{l}\text { Območje, pomembno } \\
\text { za skupnost (SCI) }\end{array}$ & 257.082 & 51.265 & 2.788 & 1,08 & 5,44 & 1.000 & 0,39 & 1,95 \\
\hline $\begin{array}{l}\text { Posebno območje } \\
\text { varstva (SPA) }\end{array}$ & 82.178 & 25.440 & 883 & 1,07 & 3,47 & 318 & 0,39 & 1,25 \\
\hline Kombinacija SCI - SPA & 381.026 & 81.306 & 5.807 & 1,52 & 7,14 & 4.747 & 1,25 & 5,84 \\
\hline Skupaj & 720.286 & 158.011 & 9.478 & $\mathbf{1 , 3 2}$ & 6 & 6.065 & $\mathbf{0 , 8 4}$ & 3,84 \\
\hline \multicolumn{9}{|c|}{ (b) Varovana območja narodnih, regijskih in krajinskih parkov ter naravnih rezervatov } \\
\hline Narodni park & 83.808 & 8.913 & 736 & 0,88 & 8,25 & 428 & 0,51 & 4,81 \\
\hline Regijski parki & 43.442 & 16.113 & 509 & 1,17 & 3,16 & 143 & 0,33 & 0,89 \\
\hline Krajinski parki & 117.004 & 47.708 & 2.534 & 2,17 & 5,31 & 236 & 0,20 & 0,49 \\
\hline Naravni rezervati & 8.675 & 1.132 & 95 & 1,10 & 8,42 & 23 & 0,25 & 1,92 \\
\hline Skupaj & 252.929 & 73.866 & 3.874 & $\mathbf{1 , 5 3}$ & 5,24 & 830 & $\mathbf{0 , 3 3}$ & 1,12 \\
\hline \multicolumn{9}{|c|}{ (c) Življenjski prostor rjavega medveda } \\
\hline $\begin{array}{l}\text { Območje izjemne/redke } \\
\text { prisotnosti }\end{array}$ & 1.095 .003 & 465.454 & 15.759 & 1,44 & 3,39 & 3.891 & 0,36 & 0,84 \\
\hline Osrednje območje & 347.625 & 65.635 & 3.030 & 0,87 & 4,62 & 2.439 & 0,70 & 3,72 \\
\hline $\begin{array}{l}\text { - Območje gostejše } \\
\text { naseljenosti ljudi }\end{array}$ & 41.653 & 18.931 & 550 & 1,32 & 2,90 & 129 & 0,31 & 0,68 \\
\hline $\begin{array}{l}\text { - Območje manjše } \\
\text { naseljenosti ljudi }\end{array}$ & 305.972 & 46.704 & 2.481 & 0,81 & 5,31 & 2.310 & 0,76 & 4,95 \\
\hline Prehodno območje & 308.523 & 55.082 & 2.431 & 0,79 & 4,41 & 1.304 & 0,42 & 2,37 \\
\hline Robno območje & 255.662 & 79.418 & 3.664 & 1,43 & 4,61 & 1.770 & 0,69 & 2,23 \\
\hline Skupaj & 2.006 .813 & 665.588 & 24.884 & 1,24 & 3,74 & 9.403 & $\mathbf{0 , 4 7}$ & 1,41 \\
\hline \multicolumn{9}{|c|}{ (d) Območja z omejenimi dejavniki (OMD) } \\
\hline DO - druga območja & 81.196 & 24.387 & 1.144 & 1,41 & 4,69 & 114 & 0,14 & 0,47 \\
\hline $\begin{array}{l}\text { HGO - hribovska } \\
\text { gorska območja }\end{array}$ & 1.467 .573 & 375.745 & 16.305 & 1,11 & 4,34 & 7.599 & 0,52 & 2,02 \\
\hline $\begin{array}{l}\text { PO - območja s } \\
\text { posebnimi omejitvami }\end{array}$ & 202.482 & 105.950 & 3.938 & 1,94 & 3,72 & 1.668 & 0,82 & 1,57 \\
\hline Skupaj & 1.751.251 & 506.082 & 21.387 & 1,22 & 4,23 & 9.380 & $\mathbf{0 , 5 4}$ & 1,85 \\
\hline \multicolumn{9}{|c|}{ (e) Vodovarstvena območja (VVO) - državni, občinski, vrelčni nivo } \\
\hline 0 & 97 & 20 & 0 & 0,14 & 0,71 & 0 & 0,01 & 0,05 \\
\hline 1 & 7.778 & 2.591 & 126 & 11,65 & 22,57 & 39 & 0,85 & 2,17 \\
\hline 2 & 67.512 & 17.637 & 995 & 5,19 & 15,48 & 618 & 1,02 & 3,95 \\
\hline 3 & 238.749 & 75.481 & 2.964 & 1,24 & 3,93 & 1.942 & 0,81 & 2,57 \\
\hline 4 & 31.303 & 8.281 & 610 & 1,95 & 7,37 & 861 & 2,75 & 10,40 \\
\hline 5 & 4.781 & 2.944 & 80 & 1,68 & 2,72 & 2 & 0,04 & 0,06 \\
\hline Skupaj & 350.202 & 106.954 & 4.776 & 1,36 & 4,47 & 3.462 & 0,99 & 3,24 \\
\hline
\end{tabular}


Rezultati za VVO potrjujejo opozorila kmetov, da se bodo območja najstrožjih vodovarstvenih režimov začela zaraščati, saj so pogoji za izvajanje običajne ekonomsko upravičene kmetijske dejavnosti zelo strogi in kmete odvračajo od obdelovanja teh zemljišč (Preglednica 5). Tako je omejena uporaba mineralnih gnojil $\mathrm{v}$ ravninskih območjih ter izvajanje paše na kraških in visokogorskih pašnikih. $Z$ vidika varovanja vodnih virov je tak trend zaželen, a po drugi strani kvari krajinsko podobo območij in socio-ekonomski položaj kmeta. Povečanje zarasti in prehajanje $\mathrm{v}$ gozdno vegetacijo ima tudi negativen vpliv, saj se poveča evapotranspiracija, kar zmanjšuje količino vode, ki napaja vodni vir (Ulaga in sod., 2008). Predlagamo, da se $\mathrm{v}$ bodoče pred uvajanjem režima predhodno preveriti kratko-, srednje- in dolgoročne vplive na kmetijsko dejavnost, vrsto dejanske rabe in možnost pojava grmovne in drevesne zarasti.

\section{SKLEPI}

$\mathrm{S}$ to raziskavo smo prvič po sprejetju prenovljenega zakona o kmetijskih zemljiščih (RS, 2011), ki v sedmem členu lastnikom, zakupnikom in drugim uporabnikom nalaga preprečevanje in odpravljanje zaraščanja, opravili prostorsko in statistično analizo $\mathrm{z}$ namenom identifikacije območij, ki so najbolj izpostavljena zaraščanju.

Raziskava je pokazala, da je zaraščanje proces, ki se pojavlja po celotni Sloveniji $\mathrm{z}$ glavnino $\mathrm{v}$ osi od jugozahoda proti severovzhodu. Analiza povezave zaraščanja s prisotnostjo gozda na območju občine je pokazala, da ni izrazitih vzorcev, ki bi potrjevali domnevo, da večji odstotek gozda pomeni večji odstotek zaraščanja. Povezave med preučevanimi razredi dejanske rabe bi bilo treba podrobno preučiti na ravni posameznega območja zaraščanja, kjer bi opravili analizo učinka sosedstva rabe 2000 na razširjenost rabe 1410 in analizo opuščanja kmetijske obdelave na zemljiščih rabe 1800 (npr. vpliv napadov zveri na pašno živino).

Površine rabe 1410 in rabe 1800 so povezane $\mathrm{z}$ naklonom in nadmorsko višino, saj se $\mathrm{z}$ večanjem vrednosti obeh spremenljivk odstotek obeh rab glede na celotno površino kmetijskih zemljišč $\mathrm{v}$ občini poveča. Analiza je pokazala, da je raba 1410 na poplavnih območjih bolj razširjena od rabe 1800. Manjši vpliv na rabo 1800 izhaja iz dejstva, da je razširjena na specifičnih lokacijah, kjer se zaradi prepustnih apnenčastih kamnin in topografije (naklon) poplave ne pojavljajo. To potrjuje tudi majhen obseg rabe 1800 (48 ha) na poplavnih območjih. Vpliv posameznega upravljavskega statusa območja na zaraščanje je težje ovrednotiti, ker se jih ponekod izvaja več vzporedno. Analiza je pokazala, da je zaraščanje večje na območjih z upravljavskim statusom. Še posebno izstopa dejstvo, da bolj kot je striktno okoljsko varovanje (kombinacija Nature 2000 območij SCI - SPA, narodni park, naravni rezervat, osrednje območje življenjskega prostora rjavega medveda, 1. in 2. kategorija VVO), večji je odstotek rabe 1410 od vseh kmetijskih zemljišč.

$\mathrm{V}$ prostoru bodo $\mathrm{z}$ nadaljnjim razvojem kmetijske tehnologije in pridelovalnih procesov vedno obstajala zemljišča, ki bodo podvržena procesom zaraščanja. Dinamiko zaraščanja ali krčitve zarasti narekuje ekonomski interes lastnikov in zakupnikov zemljišč. Raziskava je pokazala, da se zaraščajo tudi kmetijska zemljišča v ravnini, saj do naklona $6 \%$ obsegajo skoraj 7.000 ha rabe 1410 in 1.700 ha rabe 1800 . Skupno te površine presegajo obseg vseh delujočih (6.077 ha) in delno delujočih (647 ha) namakalnih sistemov Sloveniji.

$\mathrm{Na}$ območjih, kjer je zaraščanje najbolj razširjeno, bi bilo treba pospešeno izvajati zakon o kmetijskih zemljiščih, ki določa odpravljanje zaraščanja na območjih z večjo boniteto zemljišč. Opraviti bi bilo treba analizo vzrokov za opuščanje kmetijske obdelave na posameznih območjih in predlagati ukrepe za preprečevanje (komasacije, izboljšanje dostopnosti, finančna spodbuda ali kazni) in odpravljanje zaraščanja (agromelioracije za izboljšanje fizikalnih, kemijskih in bioloških lastnosti tal, rekultivacija s pomočjo drobnice) ter nadaljnjo obdelavo zemljišč, ki bi ustrezala naravno pridelovalnim razmeram območja (reja avtohtonih pasem, izdelki z dodano vrednostjo, npr. sivka s Krasa), načrtno pogozdovanje (biomasa, plantaže gozdnega drevja). Podatki o dejanski rabi zemljišč kažejo, da se proces zaraščanja nadaljuje, zato bi morali odločevalci nadaljevati aktivnosti, ki spodbujajo preprečevanje in odpravljanje zaraščanja (ARSO, 2016). Vendarle je pomembno, da vlogo pri tem prevzamejo tudi lokalne skupnosti, ki bolje poznajo razmere na terenu in možnosti izkoriščanja prostora.

Dober ukrep za zmanjševanje zaraščanja je, v januarju 2017 sprejeta, uredba o izvajanju ukrepa odpravljanja zaraščanja na kmetijskih zemljiščih, katere izvajanje se financira s sredstvi, zbranimi iz naslova odškodnine zaradi spremembe namembnosti zemljišč (RS, 2017). Uredbo je pripravilo Ministrstvo za kmetijstvo, gozdarstvo in prehrano $\mathrm{z}$ namenom financiranja izvedbe agromelioracij na kmetijskih zemljišči $\mathrm{v}$ zaraščanju, $\mathrm{s}$ čimer bi jih ponovno usposobili za kmetijsko pridelavo. A uredba ureja le odpravljanje zaraščanja in ne deluje preventivno. Zato bo $\mathrm{v}$ prihodnje treba določiti tudi ukrepe za preprečevanje zaraščanja, kot so preprečevanja plazenja, odvodnjavanje talne vode, 
izgradnja teras, odpravljanje skalovitosti in izravnave terena, izgradnja poljskih in gozdnih poti, vzdrževanje osuševalnih sistemov in komasacije preko povečevanja površine kmetijskih parcel. Preventivni ukrepi preprečujejo zaraščanje, kar je dolgoročno finančno in energijsko učinkoviteje. Pomembno je, da s preventivnimi ukrepi omogočimo, da je zemljišče ves čas v pridelovalni funkciji in da $\mathrm{z}$ vlaganji izboljšujemo dostopnost in pridelovalni potencial zemljišč.

\section{ZAHVALA}

Delo je bilo financirano strani Javne agencija za raziskovalno dejavnost Republike Slovenije (ARRS) in Ministrstva za kmetijstvo, gozdarstvo in prehrano (MKGP) v okviru Ciljnega raziskovalnega programa.
Naslov projekta je Strokovne podlage za določitev območij primernih za odpravljanje zaraščanja (V41149).

\section{VIRI}

ARSO. 2011. Geoportal ARSO. Ljubljana. Ministrstvo za okolje in prostor. Agencija Republike Slovenije za okolje. http://gis.arso.gov.si/geoportal/catalog/main/home. page (23. nov. 2011)

ARSO. 2016. [KM10] Sprememba rabe zemljišč in kmetijstvo. Kazalci okolja Slovenije. Agencija Republike Slovenije za okolje. http://kazalci.arso.gov.si/?data=indicator\&ind_id=4 60 (30. dec. 2016)

Bordjan D., Bordjan A. 2014. Effects of overgrowing at Cerknica Polje (southern Slovenia) on breeding farmland birds/ Vpliv zaraščanja Cerkniškega polja (južna Slovenija) na gnezdilke kmetijske krajine. Acrocephalus, 35: 153-163. doi:10.1515/acro-20140009

Cojzer M. 2011. Značilnosti zaraščanja in možnosti usmerjanja sukcesijskega razvoja sestojev pionirskih drevesnih in grmovnih vrst na novonastalih gozdnih površinah. Doktorska disertacija. Ljubljana, Univerza v Ljubljani, Biotehniška Fakulteta, Oddelek za gozdarstvo in obnovljive vire: $195 \mathrm{str}$.

Corbelle Rico E., Crecente Maseda R., Sante Riveira I. 2012. Multi-scale assesment and spatial modelling of agricultural land abandonment in a European peripheral region: Galicia (Spain), 1956 - 2004. Land Use Policy, 29: 493-501. doi:10.1016/j.landusepol.2011.08.008

Černe R., Jerina K., Jonozovič M., Kavčič I., Stergar M., Krofel M., Marenče M. 2010. Škode od volkov v Sloveniji - analiza v okviru projekta Life+ SloWolf Akcija A4. Ljubljana, Zavod za Gozdove; Univerza v Ljubljani, Biotehniška fakulteta, Oddelek za gozdarstvo in obnovljive gozdne vire, Ljubljana: 12 str.
Cunder T. 1998. Zaraščanje kmetijskih zemljišč v slovenskem alpskem svetu. Sonaravni razvoj v slovenskih Alpah in sosedstvu. V: 1. Melikovi geografski dnevi, Kranjska Gora, 5-7 nov. 1998. Ljubljana, Univerze v Ljubljani, Filozofske fakultete, Oddelek za geografijo: 165-175

Diaz G.I., Nahuelhual L., Echeverria C., Marin S. 2011. Drivers of land abandonment in Southern Chile and implications for landscape planning. Landscape and Urban Planning, 99: 201-217. doi:10.1016/j.landurbplan.2010.11.005

EC. 1980. Effects on environment of the abandonment of agricultural land. Brussels, Commission of European Communities: 193 str. http://aei.pitt.edu/36390/1/A2517.pdf (31. avg. 2012)

Eler K., Čop J., Vidrih M. 2008. Trajnostna raba pašnikov Primorskega krasa v prihodnosti. V: Novi izzivi v poljedelstvu, Rogaška Slatina, 4-5 december 2008: 358-364

EU. 2013. Assessing the risk of farmland abandonment in the EU - Final report. Luxembourg, European Commission, Joint Research Centre, Institute for Environment and Sustainability: 132 str. http://ec.europa.eu/agriculture/externalstudies/2013/farmland-abandonment/fulltext_en.pdf (12. apr. 2013)

FAO. 2006. The role of agriculture and rural development in revitalizing abandoned/depopulated areas. Latvia, Riga, Comission on Agriculture, 34th Session of the European Comission: 24 str.

http://www.fao.org/fileadmin/user_upload/Europe/docu ments/Publications/Abandoned_en.pdf (1. jun. 2013)

FAO. 2010. Global Forest Resources Assessment. Rim, Food and Agriculture Organization of the United 
Nations $\quad$ (FAO): $378 \quad$ str. http://www.fao.org/forestry/fra/fra2010/en/ (9. jun. 2013)

FAOSTAT. 2013. Food and Agricuture Organization of the United Nations. http://faostat3.fao.org/home/E (2. jul. 2013)

Garcia Ruiz J.M., Lana Renault N. 2011. Hydrological and erosive consequences of farmland abandonment in Europe, with special reference to the Mediterranean region - A review. Agriculture, Ecosystems and Environment, 140: 317-338. doi:10.1016/j.agee.2011.01.003

Gellrich M., Zimmermann N.E. 2007. Investigating the regional - scale pattern of agricultural land abandonment in the Swiss mountains: A spatial statistical modelling approach. Landscape and Urban Planning, 69: 65-76. doi:10.1016/j.landurbplan.2006.03.004

Glavan M., Kozinc Z., Pintar M. 2015. Kmetijstvo in upravljanje s poplavnimi območji ob reki Dravi projekt LiveDrava. Zbornik referatov - Mišičev vodarski dan 2014. Maribor, Vodnogospodarski biro Maribor: 8-15. http://www.mvd20.com/zbornik.php?page=letnik (9. dec. 2015)

GURS. 2011. Zbirke prostorskih podatkov. 2011. Ljubljana, Geodetska uprava RS. http://www.eprostor.gov.si/si/zbirke_prostorskih_podatkov/ (23. nov. 2011)

Gutman L. 2011. Rekultivacija zaraščajočih kmetijskih zemljišč s pašo domačih živali na območju krajinskega parka Goričko. Diplomsko delo. Ljubljana, Univerza v Ljubljani, Biotehniška Fakulteta, Oddelek za agronomijo: 40 str.

Hladnik D. 2005. Spatial structure of disturbed landscapes in Slovenia. Ecological Engineering, 24: 17-27. doi:10.1016/j.ecoleng.2004.12.004

Hočevar M., Kušar G., Cunder T. 2004. Monitoring in analiza zaraščanja kraške krajine $\mathrm{v}$ GIS okolju. Zbornik gozdarstva in lesarstva, 75: 21-52 http://rkg.gov.si/GERK/documents/RABA_IntKlju c_20110101.pdf (5.jan. 2012)

Ilc R. 2008. Zaraščanje kmetijskih zemljišč na območju Ribniško - Kočevske doline. Diplomsko delo. Ljubljana, Univerza v Ljubljani, Biotehniška Fakulteta, Oddelek za zootehniko: 52 str.

Jankovič J. 2003. Nekdaj goli Kras spet gozdnat. Sodobno kmetijstvo, 36, 6: 12-18

Jarni K. 2011. Vpliv antropogenih virov hrane na prostorsko razporeditev rjavega medveda (Ursus arctos). Diplomsko delo. Ljubljana, Univerza $\mathrm{v}$
Ljubljani, Biotehniška Fakulteta, Oddelek za biologijo: 65 str.

Keenleyside C., Tucker G. M. 2010. Farmland Abandonment in the EU: an Assessment of Trends and Prospects. Report prepared for WWF. London, Institute for European Environmental Policy: 93 str. http://www.ieep.eu/assets/733/Farmland_abandonm ent_in_the_EU_-

_assessment_of_trends_and_prospects_-

_FINAL_15-11-2010_.pdf (18.jan. 2011)

Ketiš, K., Eler, K., Udovč, A., Batič, F. (2014). Dependence of the conservation status of acid grasslands at the Pohorje and Kozjak on socioeconomic parameters. Acta agriculturae Slovenica, $103 \quad$ (2), $233 \quad$ - 244. doi:10.14720/aas.2014.103.2.8

Khanal N.R., Watanabe T. 2006. Abandonment of agricultural land and its consequences - a case study in the Sikles area, Gandaki basin, Nepal Himalaya. Mountain Research and Development, 26, 1: 32-40. doi:10.1659/02764741(2006)026[0032:AOALAI]2.0.CO;2

Knap M. 2008. Rekultiviranje zaraščenih površin s kozami na območju Notranjskega regijskega parka. Diplomsko delo. Ljubljana, Univerza v Ljubljani, Biotehniška Fakulteta, Oddelek za zootehniko: 42 str.

Kralj T., Koren D. 2011. Analiza stanja kmetijstva. V: Izhodišča za Načrt upravljanja Triglavskega narodnega parka 2012-2022. Kus Veenvliet J. (Ur.). Bled, Javni zavod Triglavski narodni park: 25 str. http://www.tnp.si/images/uploads/analiza_kmetijstv a.pdf (18. nov. 2015)

Krebs C.J. 2001. Ecology: The experimental analysis of distribution and abundance (5th Edition). San Francisco, Benjamin Cummings: 608 str.

Kus Veenvliet J. 2012. Analiza doseganja ciljev Strategije ohranjanja biotske raznovrstnosti V Sloveniji. Končno poročilo. Naročnik: Ministrstvo za okolje in prostor. Nova vas, Zavod Symbiosis: 235 str.

MacDonald D., Carbtree J.T., Wiesinger G., Dax T., Stamou N., Fleury P., Lazpita Guiterrez J., Gibon A. 2000. Agricultural abandonment in mountain areas in Europe: Environmental consequences and policy response. Journal of Environmental Management, 59: 47-69. doi:10.1006/jema.1999.0335

Miličić V., Perpar A., Kramarič F., Udovč A. 2011. Analiza stanja kmetijstva na območju krajinskega parka Ljubljansko barje - končno poročilo revidirano in dopolnjeno besedilo. Naročnik: Javni zavod Krajinski park Ljubljansko barje. Ljubljana, 
Univerza v Ljubljani, Biotehniška fakulteta, Oddelek za agronomijo, Katedra za agrometeorologijo, urejanje kmetijskega prostora, ekonomiko ter razvoj podeželja: 90 str.

MKGP. 2011. MKGP portal. Ministrstvo za kmetijstvo, gozdarstvo in prehrano. http://rkg.gov.si/GERK/ (23. nov. 2011)

MKGP. 2012. Interpretacijski ključ - podroben opis metodologije zajema dejanske rabe kmetijskih gozdnih zemljišč. Ljubljana, Ministrstvo za kmetijstvo, gozdarstvo in prehrano.

MOP. 2002. Strategija upravljanja $\mathrm{z}$ rjavim medvedom (Ursus arctos) v Sloveniji. Ljubljana, Ministrstvo za okolje in prostor: 31 str. http://www.mop.gov.si/fileadmin/mop.gov.si/pageu ploads/podrocja/velike_zveri/strategija_rjavi_medv ed_2002.pdf (15. dec. 2011)

MOP. 2007. Akcijski načrt upravljanja z rjavim medvedom (Ursus arctos L.) v Sloveniji. Ljubljana, Ministrstvo za okolje in prostor: 23 str. http://www.mop.gov.si/fileadmin/mop.gov.si/pageu ploads/podrocja/velike_zveri/akcijski_nacrt_medve d_predlog_apr07.pdf (15. dec. 2011)

Plut D. 2011. Prehranska varnost planeta in Slovenije. Ljubljana, Svet za varstvo okolja Republike Slovenije: $4 \quad$ str. http://www.mko.gov.si/fileadmin/mko.gov.si/pageu ploads/svo/53seja_Plut.pdf (5. maj 2013)

Pogačnik M., Kompan D., Vidrih T., Kotar M., Matičič B. 1995. Rekultiviranje opuščenih hribovitih kraških zemljišč z drobnico. Sodobno kmetijstvo, 28, 5: 225-229

Pogačnik M, Batič F. 2006. Sistemi sobivanja domačih in divjih živali - zaključno poročilo - CRP "Konkurenčnost Slovenije 2001-2006". Ljubljana, Univerza v Ljubljani, Veterinarska fakulteta: 13 str.

Pogačnik A., Foški M., Drobne S., Konjar M., Soss K., Lipar P., Brilly M., Vidmar A., Žura M., Juvanc A., Maher T., Marsetič R., Detellbach S., Strnad I., Šemrov D., Fatur M. 2011. Analiza stanja, razvojnih teženj ter usmeritev za strateški prostorski razvoj Slovenije - zaključno poročilo CRP "Konkurenčnost Slovenije 2006-2013". Univerza v Ljubljani, Fakulteta za gradbeništvo in geodezijo, Ljubljana: 249 str.

Poyatos R., Latron J., Llorens P. 2003. Land use and land cover change after agricultural abandonment the case of a mediterranean mountain area (Catalan pre-pyrenees). Mountain Research and Development, 23, 4: 362-368. doi:10.1659/02764741(2003)023[0362:LUALCC]2.0.CO;2
Renwick A., Jansson T., Verburg H.P., Revordero Giha C., Britz W., Gocht A., McCracken D. 2013. Policy reform and agricultural land abandonment in the EU. Land Use Policy, 30: 446-457. doi:10.1016/j.landusepol.2012.04.005

RS. 2004a. Uredba o posebnih varstvenih območjih. Ur. 1. RS, št.49/04, 110/04, 59/07, 43/08, 8/12, 33/13, $35 / 13$ - popr., $39 / 13$ - odl. US in 3/14

RS. 2004b. Zakon o ohranjanju narave. Uradni list RS, št. 96/04, 61/06 - ZDru-1, 8/10 - ZSKZ-B in 46/14

RS. 2004c. Pravilnik o kriterijih za določitev vodovarstvenega območja. Uradni list RS, št. $64 / 04,5 / 06,58 / 11$ in 15/16

RS. 2008. Pravilnik o določanju in vodenju bonitete zemljišč. Ur. 1. RS, št. 47/08

RS. 2011. Zakon o kmetijskih zemljiščih. Ur.l. RS, št. $71 / 11$ in $58 / 12$

RS. 2015. Pravilnik o razvrstitvi kmetijskih gospodarstev v območja $\mathrm{z}$ omejenimi možnostmi za kmetijsko dejavnost. Ur.l. RS, št. 12/15 in 84/16

RS. 2017. Uredba o izvajanju ukrepa odpravljanje zaraščanja na kmetijskih zemljiščih. Ur.l. RS, št. $3 / 17$

SURS-GIS. 2011. Baza geostatistični podatkov Statističnega urada Republike Slovenije. http://www.stat.si/gis/ (23. nov.2011)

SURS-STAT. 2012. Statistični letopis 2012. Ljubljana, Statistični urad Republike Slovenije http://www.stat.si/StatWeb/glavnanavigacija/podat $\mathrm{ki} /$ publikacije/statisti\%C4\%8Dni-letopis?leto=2012 (2. jul. 2013)

Ulaga F., Kobold M., Frantar P. 2008. Analiza časovnih sprememb vodnih količin slovenskih rek. Zbornik referatov - Mišičev vodarski dan 2008. Maribor, Vodnogospodarski biro Maribor: 9-17 http://www.mvd20.com/zbornik.php?page=letnik (17. nov. 2015)

Vidrih T. 2005. Drevesno-pašna raba. Naše travinje, 1, 1: 6-8.

Vidrih T. 2010. Ciljna paša na posekah kraškega pašnika. Naše travinje, 6, 1: 4-6

Vidrih T., Pogačnik M., Kotar M., Kompan D., Juntes P., Matičič B. 1996. Cilji in naloge razvojno raziskovalnega centra za rekultiviranje opuščenih kraških in hribovitih površin Vremščica. V: Možnosti razvoja reje drobnice v Sloveniji, Postojna, Hotel Jama, 27-29 november 1996. Slovenj Gradec, Kmetijska založba: 73-78

Vodlan M. 2006. Poraba energije pri čiščenju zaraščenih kmetijskih zemljišč na dveh lokacijah v 
Sloveniji. Diplomsko delo. Ljubljana, Univerza v Ljubljani, Biotehniška Fakulteta, Oddelek za agronomijo: 43 str.

Vrščaj B. 2008. Strukturne spremembe kmetijskih zemljišč. Njihova urbanizacija in kakovost $\mathrm{v}$ obdobju 2002 - 2007. Hmeljarski bilten, 15: 73-84 Wilfing H. 1993. Ekologija. Celovec: Mohorjeva založba: 120 str.

www.fao.org/world/regional/reu/eca/eca_en/eca34_3.pd f (18. jul. 2013)

Zaragozi B., Rabasa A., Rodriguez Sala J.J., Navarro J.T., Belda A., Ramon A. 2012. Modelling farmland abandonment: A study combining GIS and data mining techniques. Agriculture, Ecosystems and Environment, 155: 124-132. doi:10.1016/j.agee.2012.03.019
ZGS. 2011. Poročilo Zavoda za gozdove Slovenije o gozdovih za leto 2011. Ljubljana, Zavod za gozdove Slovenije: $133 \quad$ str. http://www.zgs.si/slo/gozdovi_slovenije/o_gozdovi h_slovenije/letna_porocila/index.html (15. apr. 2015)

Žvikart M. 2013. Analiza ciljev in ukrepov programa upravljanja območij Natura 2000 - Operativni program upravljanja z območij Natura 2000 v Sloveniji 2014-2020 - SI Natura 2000 Management - akcija A1, A2 - Sektor kmetijstvo. Ljubljana, Zavod RS za varstvo narave: 38 .

Žgavec, D., Eler, K., Udovč, A.,Batič; F. (2013). Contribution of agricultural policy measures to maintain grassland areas (the case of Radensko Polje Landscape Park). Acta agriculturae Slovenica, letnik 101(1), 77-86 